\title{
Verbond en volkskerk
}

\author{
AD Pont
}

\section{Abstract \\ Covenant and volkskerk}

The Nederduitsch Hervormde Kerk states in its Church Order that it is a volkskerk. This designation does not immediately signify that it is a nationally exclusive church. A historical line is researched to try and assess what the term volkskerk does imply. The 16 th century calvinist position is examined and then the situation during the reign of the Dutch East India Company of the Cape from 1652-1795. The Patriot-period is investigated and also the position of the Church of the Voortrekkers as well as in the old Zuid-Afrikaansche Republiek. Historically speaking, the structure of the covenant of grace and Art 36 of the Confessio Belgica give the true meaning of the term volkskerk as used by the Nederduitsch Hervormde Kerk till 1899. However, it is clear that the term volkskerk in the contemporary Order has another content than the meaning which it carried in the previous century.

\section{INLEIDING}

In die Kerkwet van die Nederduitsch Hervormde Kerk van Afrika kom dit in Artikel III tot uiting dat die Kerk homself as 'n volkskerk beskou. Oor die volikskerk het Botha (1973) 'n belangrike brosjure gepubliseer, die eerste publikasie in ons kerklike kring wat enigsins volledig aan hierdie saak aandag gegee het. Hierin het hy ook die historiese groei van die begrip nagegaan. Daar is egter nog enkele fasette van die volkskerk-opvatting waarop vérder ingegaan kan word en wat van belang is om die inhoud en omvang van die begrip by ons te presiseer. Dit veral omdat die volkskerk in Nederland in ' $n$ bepaalde historiese situasie en in 'n spesifieke staatkundige bedeling na vore gekom het. In die Suid-Afrikaanse situasie is die staatkundige bedeling wat deur die Voortrekkers en die oprigters van die ou Zuid-Afrikaansche Republiek geskep is, nie sonder verband met die opkoms en groei van die volkskerk-opvatting nie. Terselfdertyd is dit duidelik dat bepaalde Skriftuurlik-teologiese opvattings 'n wesenlike bydrae gelewer het tot die soort volksgemeenskap of maatschappij wat die vadere gedurende die 19 de eeu buite die Kaapkolonie gevestig het. Die vadere se vorm- 
gewing van hulle maatschappij is juis interessant omdat dit teen die grein loop van die rasionalistiese denke wat in Europa en ook in Engeland gedurende die 18de en 19de eeu byna vanselfspekend was.

Dit wil voorkom asof die vadere se vormgewing van hulle volksgemeenskap en die verhouding daarin van die owerheid en die kerk tot mekaar, bygedra het, nie alleen tot die beskuldiging dat ons kerk liberaal is nie, maar ook tot die wyse waarop die Algemene Kerkvergadering in 1885 gepoog het om 'n kerkvereniging in die ZAR tot stand te bring.

Die mislukking van die kerkvereniging van 1885 , verteenwoordig 'n mislukte poging om twee botsende opvattings oor gemeenskap, volk en kerk met mekaar te probeer versoen, terwyl dit nie moontlik was nie.

Dit is duidelik dat dit nie moontlik sal wees om in hierdie bestek alles volledig na te gaan met inagneming van alles wat hier ter sake is nie. Dit gaan hier in hoofsaak om vas te stel hoe die opvatting van die volkskerk vanuit die 16de-eeuse teologie en die teologies-bepaalde opvattings oor volk-gemeenskap èn kerk gegroei het. Uit die aard van die saak sal in hierdie konteks ook aandag gegee moet word aan die owerheid en die volk-gemeenskap. Daar kan, miskien ten oorvloede, net daarop gewys word dat die begrip staat, as 'n versamelbegrip vir die geheel van die struktuur van vaderland-volk-kerk-owerheid, eers in die $18 \mathrm{de}$ eeu na vore kom en as sodanig nie baie deur die Afrikaners gebruik word in die 18 de en 19 de eeu nie.

In hierdie ondersoek word in hoofsaak aan drie historiese periodes aandag gegee om daar die nodige gegewens te vind, naamlik die tyd van die Kerkhervorming, en dan spesifiek in Switserland; die situasie in Nederland in die periode tot 1651 wat oorgedra word na die Kaapkolonie deur die VOC; en in die derde plek die opvattings van die Voortrekkers en die grondlêers van die ou Zuid-Afrikaansche Republiek.

\section{DIE HERVORMING IN SWITSERLAND}

In die eerste plek is dit nodig om aandag te gee aan die fundamentele riglyne wat neergelê word vir die strukturering van volk en gemeenskap èn die kerk in Switserland. Dit is veral Zwingli wat in Zürich die eerste hieraan aandag moes gee. Sy aanvanklike opvattings en reëlings soos gewysig en bepaal deur die staatsowerheid van Zürich (Locher 1979: $615 \mathrm{vv}$ ) was vir 'n groot deel bepalend vir die strukture wat in die res van Reformatoriese Switserland gegeld het. Soos reeds aangetoon 
(Pont 1985: 429-431) kan die Reformatore se opvatting oor die volksgemeenskap alleen teen die agtergrond van die Middeleeuse Roomse corpus christianum-denke verstaan word (Neuser 1967: 50-53). Omdat elke mens in die Westerse wêreld kragtens rykswet gedoop moes wees, was die sigbare kerk èn die volk vir alle praktiese redes identies be- $/$ skou. By Clairvaux en Aquinas, is dit opvallend dat die respublica christiana en die ecclesia volledige sinonieme is. Hoewel dié opvatting van Aquinas nie die enigste in dié verband was nie, was dit ' $n$ weergawe van die algemeen-aanvaarde opvatting (Pont 1985: 429) en is dit die agtergrond van die Reformatore se opvattings oor die volksgemeenskap, kerk en owerheid.

Die Roomse opvatting van die volksgemeenskap as corpus christianum word deur die Reformatoriese vadere, Luther, Zwingli-Bullinger en Calvyn, om maar slegs dié drie te noem, gewysig. Die wysiging begin omdat die Reformatore met 'n ander kerkbegrip na vore kom. Die Reformatoriese argument is: Nie alle mense wat lid van die sigbare kerk is, is uitverkorenes of lede van die volk van God op aarde nie. Die sigbare kerk is altyd 'n corpus permixtum. Hierdie sigbare kerk is die breë onderbou van die onsigbare of ware kerk, die gemeenskap van die heiliges wat slegs deur God geken word. Tog is die sigbare kerk voluit kerk solank die kerk nog in die wêreld is en stryd voer teen sy gebreke en tekortkominge. Omdat Christus self die kerk deur sy vergiffenis van die sonde dra, is die kerk in die wêreld heilig. Deur hierdie onderskeiding in die kerk, het die Reformatoriese vadere die Rooms-Katolieke opvatting van die corpus christianum waar kerk en volksgemeenskap saamval, deurbreek.

Die merkwaardige is egter dat in die praktyk sommige Reformatore tog die corpus christianum-opvatting behou. Dit vind veral by die Zürichse teoloë plaas. Die doop, wat ook na die Hervorming, deur die landswet verplig word, is óók opname in die sigbare kerk en as sodanig opname in die verbond van God met sy volk. Daarom word in Zürich en elders die weiering om ' $n$ kind te doop, nie net as kettery nie, maar ook as oproer, verbreking van die burgerlike orde beskou. So ontstaan daar 'n duidelike spanning tussen die teologiese uitsprake oor die kerk en die praktiese werklikheid van die lewe van elke dag.

In Zürich word dan die reël gevolg dat elkeen wat gedoop is en so lid van die verbond is, verplig is om na die eis en reël van die verbond, dit wil sê gelowig en vroom, te lewe. Ook die naam-Christen wat wel gedoop is, maar wat nie werklik tot die geloof gekom het nie en tog formeel lid van die sigbare kerk en die verbond is, bly onderworpe aan 
die verbond wat nie alleen die mens se verhouding tot God omskryf nie, maar ook die norme en standaarde van die Christelike gemeenskap vaslê. So ontstaan die christelike gemenebes, die gedoopte volk wat in een gemeenskap, stad of volk saamgesnoer is. Die taak of opdrag van die sigbare kerk is om deur die verkondiging van die Woord die gedoopte lede van kerk en gemenebes op te voed en te bewaar in die gehoorsaamheid aan God en sy Woord. Deur die prediking wat die geloof wek en voed, word die gelowiges in een liggaam sáam verbind. Terselfdertyd is dit die taak van die sigbare kerk om deur middel van die tug die dissipline in die liggaam van die kerk te handhaaf, met die ban as uiterste middel. In dié tughandeling is die Woord van God, soos verstaan en uitgelê deur die ampsdraers, die begin en die einde van dié hele dissiplinêre proses.

In Zürich, waar Zwingli en na hom Bullinger, groot klem op die verbondsmatige karakter van die gemenebes lê, bestaan die sigbare kerk nie as ' $n$ aparte gemeenskap in die gemenebes nie, maar is die kerk self die volksgemeenskap. Dit bring mee dat die christianus Magistratus en die predikant elk sy plek binne dieselfde gemeenskap het of dit nou verbond, kerk, gemeenskap of gemenebes genoem word (vgl Baker 1980: $107 \mathrm{vv}$ ). In hierdie situasie is die volkskerk of staatskerk volkome vanselfsprekend.

As Calvyn in 1536 in Genève aankom, bestaan daar, na die voorbeeld van Bern en Zürich, reeds so 'n volks- of staatskerk. Dié bedeling waar die Raad, nadat die predikant aangehoor is, alle kerklike beslissings neem, was vir Calvyn nie aanvaarbaar nie. Juis dit gee aanleiding tot Calvyn se verbanning in 1538 en na sy terugkeer in 1541 word 'n geweldige groot deel van Calvyn se tyd bestee aan sy pogings om die handhawing van die tug in die hande van die kerklike vergadering terug te plaas.

Hoewel Calvyn die volk as gedoopte volk aanvaar, wil hy nie verbond en gemenebes (soos in Zürich) met mekaar identifiseer nie, maar eerder verbond en kerk om sodoende 'n volkome selfstandige kerk in die gemenebes op te rig. Hierdie opvattings kon Calvyn slegs in 'n beperkte mate in Genève verwerklik en in die 16de eeu het die owerhede in Genève steeds getrag om die kerk daar in 'n staats-onderhorige kerk te omvorm (Wesel-Roth 1954: 116). Calvyn het hom voortdurend daarteen verset. Tog bly dit opvallend dat Calvyn in sy Institusie stel dat beide die burgerlike en die kerklike regering bepaal word deur die omvattende geheel van die genadeverbond (Calvyn 1559: III, 19, 15) wat die geheel van die gedoopte volk omvat. Calvyn stel dat die 
heerskappy van God oor sy verbondsvolk gerealiseer word deur sowel die burgerlike as die kerklike regering (Calvyn 1559: IV, 20, 2). Daarom is, binne die raamwerk van die verbond, owerheid en kerk onlosmaaklik aan mekaar gekoppel (Jacobs 1971: 22), want inhoud en vorm word deur die verbond aan sowel die burgerlike as aan die kerklike regering gegee (Calvyn 1559: IV, 20, 9).

Aan die ander kant onderskei Calvyn ook baie duidelik tussen die burgerlike en kerklike regering. Immers God se heilshandeling en die owerheid se handhawing van die burgerlike rus en orde, lê op verskillende vlakke en nie in mekaar se verlenging nie. Tog is dit so dat God, die Heilige Gees, deur die twee diakonoi, die owerheid en die kerk, die een Christelike gemeenskap-volk regeer (Calvyn 1559: IV, 20, 4). Daarom lê die taak van die burgerlike owerheid vir Calvyn ook verder as die diesseits en is die burgerlike regering vir hom nooit ' $n$ doel in homself nie.

Die verhouding van die owerheid en volk sien Calvyn as 'n verdragsof ooreenkoms-verhouding en daarmee kies hy vir die natuurregtelike tradisie in hierdie verband (Jacobs 1971: 23). Dié verdrag tussen owerheid en volk (Calvyn 1559: IV, 20,9) val vir'n baie groot deel saam met die verbond, want die verbond normeer in die respublica christiana die burgerlike regering.

Calvyn grens voortdurend teen die Zürichse opvatting af waar die verbond sonder meer die basis van die pneumatokratiese owerheid en burgerlike gemenebes is en die staat as ' $n$ heilige Godstaat verstaan word. Juis deur duidelik tussen die burgerlike en kerklike regering te onderskei en aan te toon dat hulle op verskillende vlakke staan, kan Calvyn hierdie misvatting in sy teokratiese visie van die respublica christiana vermy. Vir 'n groot deel word dit bepaal deur die feit dat Calvyn die genadeverbond nie as ' $n$ bilaterale verhouding tussen God en mens, soos by die Zürichse teoloë, verstaan nie (Baker 1980: 197). Calvyn sien die genadeverbond primêr as 'n testament waar God, op grond van die soenverdienste van Jesus Christus, sy genadegawes aan die mens gee. Dit hang saam met Calvyn se siening dat die genadeverbond die gevolg van die uitverkiesing is, terwyl by Bullinger die verbond aan alles voorafgaan (Wendel 1978: $209 \mathrm{vv}$ ). Dit bring mee dat in die Calvinistiese teologie ' $n$ ánder lyn gevolg word as by die Zürichse teoloë en hulle opvolgers. Daarom is dit, vir die doeleindes van hierdie uiteensetting, tog nodig om ' $n$ oomblik te let op die uiteensetting van Caspar Olevianus, De substantia foederis gratuiti inter Deum et electos van 1558. 
In hierdie eerste sistematiese uiteensetting van die verbond in die Calvinistiese teologie word dit duidelik dat die struktuur van die verbond nie net so met die gedoopte volk of gemeenskap gelykgestel word nie. Die opvatting oor die Christelike gemenebes en die plek en taak van die kerk en die burgerlike owerheid word in hierdie teologie nie direk van die verbondsgedagte afgelei nie. Dit blyk as Olevianus se denke nagegaan word. Hy begin sy uiteensetting in hierdie verband deur tussen twee verbonde te onderskei.

Die eerste verbond is ' $n$ verbond van die werke wat na die sondeval die juridiese of natuurlike verbond word. Daarvolgens eis God van die mens volkome gehoorsaamheid aan sy wet, soos dit in die natuur en in die Tien Gebooie gegee is. Omdat geen mens aan die voorwaardes kon voldoen nie, het God die tweede onvoorwaardelike verbond van genade opgerig. Dié verbond word alleen deur God in stand gehou sonder enige menslike teenprestasie.

Hierdie verbond van genade is op die uitverkiesing gebaseer waarvolgens God, in sy vrye genade, sommige uitverkies as erfgename van sy testament. Hulle ontvang dan die genadegawe van geloof, terwyl diegene wat nié uitverkies is nie, uit die testament-verbond van die genade uitgesluit is. Uit dié uiteensetting word dit duidelik dat die verbond nie as die vertrekpunt vir die verstaan van die volk of die gemeenskap gesien word nie. Só, soos Olevianus die verbond teken, is dit die basis van die kerkbegrip en verklaar dit die onderskeiding in sigbare en onsigbare kerk. Die verbond van die genade wat by Olevianus met die leer van die uitverkiesing saamval, bepaal die siening van die kerk. So, soos Olevianus die verbond aan die uitverkiesing koppel, is die verbond óók nie die basis vir ' $n$ volkskerk-opvatting nie.

Olevianus se opvattings oor die verbond het nogal 'n breë nawerking gehad, maar dit was nie altyd bepalend vir die opvattings wat in die Calvinistiese teologie oor die organiese samehang van volk, kerk en owerheid gehuldig is nie.

Die onderskeiding van Olevianus tussen die twee verbonde het spoedig algemene aanvaarding gevind en het in Calvinistiese kringe byna dieselfde rol gespeel as Luther se onderskeiding tussen die wet en die evangelie. Dit nieteenstaande die feit dat sy argumente nie net so by Calvyn teruggevind word nie.

In die laat sestiende en sewentiende eeu waar die ortodokse Calvinisme veral gekenmerk word deur 'n streng en al meer skolastieke predestinasieleer, is Olevianus se skema van die samehang tussen uitverkiesing en verbond feitlik algemeen aanvaar. Juis die beklemto- 
ning van die uitverkiesing en die absolute objektiwiteit van die genade teenoor die semi-Pelagiane en Arminiane het meegebring dat die voorwaardelike, bilaterale verbond, soos Bullinger dit na vore gebring het, geleidelik op die agtergrond geraak het. Dit het meegebring dat die verbond nie meer as die omskrywing van die organiese samehang van volk-kerk-owerheid gebruik is nie. Die verbond van die werke kon nog hiervoor gebruik word, maar die verbond van die genade is byna uitsluitlik gebruik as ' $n$ teologiese basis vir die ekklesiologie. Tog het Bullinger, oftewel die Zürichse opvatting oor die verbond in Nederland, nie heeltemal verdwyn nie, hoewel die voorwaardelike bilaterale verbondsopvatting tog in duidelike spanning met die sola fide van die Reformatore en 'n strikte predestinasieleer staan. Juis die hantering van die predestinasieleer en veral die skolasties-formele wyse waarop dit hanteer is, het reaksie uitgelok. Dié reaksie het veral 'n hernude belangstelling vir die verbond gevra. Dit was veral in die Puritanisme, met sy invloed na die Nederlandse Nadere Reformasie, waar dié saak na vore kom. Nog steeds is die basiese voorwaarde vir die verlossing van die mens die genadegawe van die geloof. Die geloof eis egter dat die gelowige in gehoorsaamheid aan die wet of die verbond van die werke sy lewe sal leef. Dan word die heiligmaking of die vrome lewenswandel die bewys en die sekerheid van die verkiesing. So is die vrye genade van God sowel as die verantwoordelikheid van die mens in die Puritanisme beklemtoon, sonder om daarmee die toets van ortodoksisme, naamlik die predestinasieleer, te bev raagteken (Miller 1939: 385-397). Dit is op hierdie punt waar die sewentiende-eeuse teoloë van die Nadere Reformasie by die Puritanisme aansluit en sodoende aan die verbondsteologie 'n nuwe lewenskrag giee.

Hierdie, enigsins uitvoerige ekskurs, is gevoer om daarmee aan te toon dat die oorspronklik Zürichse opvatting oor die verbond as die basis van die gemeenskap of gemenebes in die Calvinisme ' $n$ minder belangrike rol gespeel het. Dit het egter nié beteken dat die organiese verbondenheid van gedoopte volk-kerk en owerheid uit die gesig verdwyn het. Twee redes kan hiervoor aangegee word: Die belydenisskrifte van die Nederlandse Kerk behandel die verbond, en die organiese eenheid van gedoopte volk-kerk-en-owerheid was in die sestiende eeu feitlik vanselfsprekend.

\section{DIE VERBOND IN DIE BELYDENISSKRIFTE VAN DIE KERK}

As hieroor gehandel word, dan kan die stelreël van Schilder (Schilder 
1977: 3) 'Men kan niet gereformeerd denken zonder over het verbond te spreken' seker in gedagte gehou word. Aangesien die belydenisskrifte in die lyn van die Calvinistiese teologie lê, is dit na die voorgaande miskien nie nodig om in te veel besonderhede in te gaan nie. Tog is dit opvallend dat die verbond in die belydenisskrifte nie baie sterk op die voorgrond staan nie, al kan gestel word dat dit die versweë vooronderstelling van die belydenisskrifte is. Schilder (1977: 3) wys daarop dat hoewel 'Verbond het lichaam van de kerk (is), het vormt de banen waarlangs de wegen van het heil gaan', die saak nié uitvoerig in ons belydenisskrifte behandel word nie omdat alles rondom die verbond dan nog nie uitgemaak was nie. Tog is rondom die belydenisskrifte heelwat oor die verbond geskryf en is dit duidelik dat die verbond in die sestiende en sewentiende eeu baie aandag gekry het (vgl Heppe 1958: 224-253; 295-322). Uiteindelik is dit net die Switserse Formula Consensus van 1675 en die Belydenis van Westminster van 1647 wat enigsins uitvoerig oor die verbond handel (vgl C F W cap VII, in Schaff 1949: III, 616-618). In ons belydenisskrifte is dit slegs die Vyf Leerreëls van Dordrecht wat die verbond behandel, hoewel dit sowel in die Nederlandse Geloofsbelydenis as in die Heidelbergse Kategismus genoem word. In die Leerreëls vorm die verbond nie 'n aparte hoofstuk nie, maar word wel aangeraak omdat die Remonstrante in die Sententia Remonstrantium van Desember 1618 daarna verwys. Aangesien dié saak uitvoerig deur Schilder (1977: 24-51) beredeneer word, is dit nie nodig om hier alles in diepte te behandel nie, maar kan net daarop gewys word dat die verbond genoem word in Hoofstuk 2, Art 8 en verder in die Verwerping van die dwalings in Hoofstuk 2 in Art 2, 4 en 5.

As op die verbond in die belydenisskrifte en in die geskrifte van die Calvinistiese teoloë van daardie tyd gelet word, word dit duidelik dat die verbond hanteer word as die basis van die ekklesiologie en nie van die gemeenskap nie (Schilder 1977: 37 en 44). Verder word ook onderskei in die verbond van die werke (foedus operum, Gal 3: 12, Gen 2: 16-17) wat God met Adam opgerig het en aan die ander kant die genadeverbond (foedus gratiae) wat God deur Jesus Christus opgerig het. Die genadeverbond het 'n duidelike testament-karakter omdat dit geldigheid kry na die dood van Jesus Christus wat as testator aangedui word. Die genadeverbond wat sowel tydens die ou bedeling as die nuwe bedeling bestaan het, het slegs verskil ten opsigte van toepassing, maar nie wat die inhoud betref nie. In hierdie skema word Christus ook aangedui as die Middelaar van die verbond (Heppe 1958: 323) en geld die verbond slegs die uitverkorenes, hoewel dáároor heelwat 
verskil van mening bestaan het. Dit is duidelik dat die genadeverbond in feite ' $n$ testament-verbond is, soos Calvyn dit reeds gestel het, en dat die mens geen teenprestasie hoef te lewer, soos in die verbond van die werke nie.

Hoewel die genadeverbond eksklusief was, het die opvatting van die verbond van die werke, waarvolgens die mens na die eis van die Goddelike wet moet lewe, meegehelp om die kerklike opvattings oor die gemeenskap en die owerheid te kleur. Dié opvattings het egter ingepas by die denke oor die samehang van kerk en koninkryk en het veral in die NGB, Art 36 'n bepaalde vorm en inhoud gekry.

\section{DIE SIENING VAN DIE ORGANIESE EENHEID VAN GEDOOPTE VOLK, KERK EN OWERHEID IN NEDERLAND}

Die Calvinisties-teokratiese visie op die struktuur van die gemeenskap, word baie duidelik in Art 36 van die NGB uiteengesit en daaruit blyk dat die corpus christianum-denke van die Middeleeue tog bly deurwerk hoewel die gemeenskap- of volksbestel eerder as 'n gemenebes of ' $n$ respublica christiana aangedui word wat deur 'n Christelike of wel hervormde owerheid regeer word. Art 36 NGB waar die teokratiese bedeling bely word, het in 1651 met die groot vergadering van die Sewe Verenigde Provinsies in Den Haag, sy praktiese uitwerking gekry. Haitjema (1964: 15) noem dié gebeure 'de publieke proclamatie van de Gereformeerde Kerkstaat'. Daar is besluit (De Visser 1926: 287-288).:

'De Staten van de respective Provintien hebben verklaerdt, ghelyk de selve verklaren mits desen, dat sy elcks in den haren vast houden ende mainteneren de ware Christelycke Gereformeerde Religie, ghelyck als deselve alomme in de publycke Kerken deser Landen jegenwoordigh wordt gepredickt en gheleert: Mitsgaders in den jare negenthien by de Synode Nationaal, gehouden tot Dordrecht, is bevestight.

Dat de selve Religie, soo by elke Provintie in den haren, als van wegen de Generaliteyt in de Quartieren onder derselver ghebiedt resorterende, met de Macht van 't Land sal ghehandhaeft worden, sonder te gedogen, dat oyt by yemandt daar inne eenige veranderinghe werden gedaen.'

Van daardie oomblik af is die beperkte godsdiensvryheid wat in die Nederlande bestaan het, afgeskaf en het die Verenigde Provinsies die karakter van 'n Calvinistiese statebond gedra. 
Die basis van hierdie denke is dat die hele volk, kragtens die doop, deel is of vormgewing is van die verbond. In hierdie teokratiese denke, soos verwoord in Art 36, is dit die plig van die owerhede, as regeerders vanweë die genade van God, om die eer van God te handhaaf in die openbare lewe en om te verhoed dat die ware diens van God deur 'openbare goddeloosheden' belemmer word. In hierdie denke het die owerheid die taak om die volkslewe te help heilig, want die Reformatoriese owerheid moet, in die openbare lewe, die twee tafels van die Wet handhaaf (Calvyn 1559: IV.20.2 e a). In hierdie siening is die ideaal van 'n heilige volkslewe, soos dit in Israel gevind word, ' $n$ voorbeeld van wat nagestreef moet word. Vanuit die Woord moet kerk en owerheid saamwerk en het die owerheid 'n besliste taak: 'sodat God deur elkeen geëer en gedien word' (NGB, Art 36). Die hele lewe en kultuur van die volk moet gekersten word sodat op dié manier die koninkryk van God bevorder kan word (vgl De Visser 1926: Dl 2:142).

Groen van Prinsterer het in hierdie verband die drie prinsipiële grondlyne van hierdie teokratiese staatsbestel soos volg aangedui (aangehaal deur Haitjema, 1964: 83-84):

'ten eerste de onderwerping van de staat aan de belijdenis van het Evangelie;

ten tweede, het ontzag der overheid als overheid voor het Woord van God;

ten derde, de erkenning door het volk als geheel van het oppergezag van Jezus Christus, aan wie alle macht toekomt, in hemel en op aarde.'

Daarby het hy aangedui dat die kerk, in so 'n Christelike gemenebes, die siel van die liggaam is. Deur die verkondiging van die Woord wat in al die geledinge van die maatskappy of gemenebes indring, ontstaan die gekerstende kultuur. Daardie kultuur is egter altyd nasionaal- of volksgebonde, want daar bestaan nie so iets soos ' $n$ 'internasionale kultuur' nie. Daarom is, in hierdie teokratiese siening van die organiese eenheid, naamlik volk, kerk en owerheid, die kerk altyd volkskerk, dus kerk mede-bepaal deur die kultuursituasie waarin die kerk leef en bestaan. Die kersteningsaksie geskied deur die handhawing van die Wet, die in-ordening van die mensbestaan in die orde van God. Daarom het in die sestiende en sewentiende eeu die predikante en die kerklike vergaderings voortdurend die owerhede aangespreek. Soos De Visser (De Visser 1926: DI 2:139-140) dit stel: 
'Ons zijn de menigvuldige verzoeken der synoden aan den overheid bekend tot het nemen van maatregelen tegen de zogenaamde "krijtende zonden". Onder deze staan wel vooraan die welke Zondagsheiliging beoogden....

Eveneens wordt er gedurig bij de overheid op aangedrongen, het vloeken en zweren, dansscholen en danskamers, pernicieuze boeken en refereinen te verbieden.... De kerk herinnerde, in een woord, de overheid onophoudelijk aan hare verplichtingen, ten aanzien van de handhaving der publieke zeden.'

So word kerk en maatskappy of gemenebes in 'n twee-eenheid saamgevat en funksioneer die owerheid, as dienaar van God, om die reg en orde van God in die gemenebes te handhaaf en te bevorder. Dit is interessant om te sien wat die Sinode van Dordrecht van die owerheid verwag het (Post-acta, soos aangehaal deur Baron van Boetselaer 1947: 4):

'... soos bidt ende versoeckt oock de voorss. Synodus gansche onderdanichlyck, dat Uwe Hooch Mogenden gelieve de voorseyde Leere, voort aen, so langhe so meer inde kercken deser landen te handhouden, bevestigen, ende beschermen, gelyck oock mede de breder Verclaringe derselver Leere....'

Hier is die taak van die kerk, as gedoopte verbondsvolk, om owerheid èn volk met die Woord te bedien sodat die koninkryk in die volk 'n gestalte sal kry. Dít wil nie sê dat die kerk die hele volk omvat of dat die volk die kwaliteit van die kerk bepaal nie, maar dat die kerk kerk van Jesus Christus in die nasionale bestaan van daardie volk is om so deur sy bestaan en veral sy prediking die gemenebes te kersten.

Dit was hierdie agtergronde en denkpatroon wat ook die basis gevorm het van die denke van die Nederlanders wat die grondslae van die Afrikanervolk aan die suidpunt van Afrika vanaf 1652 gelê het.

\section{DIE TEOKRATIESE VISIE SOOS OORGEDRA NA DIE KAAP}

Die vestiging van ' $n$ verversingspos aan die Kaap ter wille van die vlote van die groot handelsmaatskappy, die Verenigde Oos-Indiese Kompanjie, het baie verder uitgegroei as wat aanvanklik beplan is. Die stigting van die verversingspos word die beginpunt van die ontstaan van ' $n$ nuwe volk in Suid-Afrika. Uit die aard van die saak het die 
grondslae wat die VOC gelê het vir die ordelike bestaan en voortbestaan van die gemeenskap rondom die fort, 'n belangrike rol gespeel in die denke en opvattings van die nuwe volk in wording.

Die Algemeene Geoctroyeerde Oost-Indische Compagnie, is op 20 Maart 1602 in Nederland opgerig hoofsaaklik ter wille van die handel met die lande en kolonies in die Ooste. Hierdie handelsliggaam het kragtens sy oktrooi onbeperkte soewereiniteitsregte ontvang in die handelskolonies wat hy gevestig het. Dit het beteken dat die handelsliggaam in sy kolonies al die regte en verpligtings van 'n owerheid ontvang het. In die organisatoriese strukture wat die VOC in sy kolonies geskep het, het hy nie juis afgewyk van die patroon wat in Nederland gegeld het nie. Die beskrywing van die Nederlandse patroon, soos Van Boetselaer (1947: 2) dit weergee, het feitlik net so in die kolonies van die VOC gegeld. Hy het dit só omskrywe:

Men leefde immers onder een Christelijke Overheid, die het als haar roeping beschouwde den Gereformeerden godsdienst te handhaven en dezen alleen toe te laten en elken andere zoveel mogelijk te weren, zonder echter consciëntiedwang uit te oefenen of tot geloofsvervolging over te gaan.'

Hoewel die saak van die godsdiens en kerk nie in die eerste oktrooi van die VOC van 1602 genoem is nie, word dit wel in die oktrooi van 1623 vermeld. Van die begin af het die VOC predikante en sieketroosters, wat vir die geestelike versorging van die Kompanjiesdienare nodig was, op sy betaalstate geplaas. Oral waar kolonies gestig is, het die Kompanjie as beskermheer van die kerk opgetree en sy ius patronatus met 'n vaste hand gehandhaaf (vgl Vorster 1956: 11).

Toe Jan van Riebeeck op 24 Desember 1651 Nederland verlaat het op pad om die verversingspos aan die Kaap te vestig, het hy ook 'n Formuliergebed saamgehad waarmee alle vergaderings van die Politieke Raad geopen moes word. Dié gebed, wat die gesindheid van die VOC goed weergee, het soos volg gelui (Godée Molsbergen 1912: 76):

'O Barmhertige Goodertieren Godt ende Hemelsche Vader, Nadien het uwe Goddelijke Majesteit geliefft heefft ons te beroepen over't bestier der saacken van de Generaale vereenighde Nederlantse $G^{\prime}$ octroyeerde Oost-Indische Comp. alhier aen de Cabo de boa Esperance ende wij ten dien eijnde met onsen bijhebbenden raedt in uwen $H$. name vergadert sijn: omme met advijs van deselve sodanige besluijten te maecken waermede den meesten dienst van de opgemelte Comp. gevoirdert, de 
Justitie gehandhaefft, ende onder dese wilde brutale menschen mogelijck sijnde Uwe ware gereformeerde Christelijcke Lere metter tijt mochte voortgeplant ende verbreijt worden, tot Uwes $\mathrm{H}$ Naems loff ende Eere, ende welstand onser Heeren Principalen, waartoe wij sonder dijne genadige hulpe 't alderminste en vermogen, soo bidden wij $u$ derhalven, $\mathrm{O}$ alderghenadighste Vader, dat gij ons met uwe vaderlijcke wijsheijt wilt bijwoonen,....'

Hieruit en uit die daaropvolgende optrede van sowel die Politieke Raad aan die Kaap as die bewindhebbers van die Kompanjie in Nederland blyk dit dat die organiese eenheid van volk, kerk en owerheid gehandhaaf is. Die kerk aan die Kaap was gedurende die Kompanjie se regeringstyd volledig volkskerk, want nie alleen is geen ander kerk aan die Kaap toegelaat nie, maar alle inwoners en werknemers van die Kompanjie was vanselfsprekend lid van die kerk. Die kerk aan die Kaap kan miskien as staatskerk aangedui word. Tog sou dit die indruk skep dat die kerk 'n sekere selfstandigheid besit het. Dit was egter nie die geval nie, want die kerk was in feite nie veel meer as 'n onderdeel van die Kompanjie nie. Dit was die Kompanjie wat predikante en sieketroosters voorsien en onderhou het, die Politieke Raad het alleen na sy goedkeuring toegelaat dat ouderlinge en diakens bevestig kon word, die Kompanjie het die kerkgeboue en pastorieë opgerig en onderhou (vgl Vorster 1956: $90 \mathrm{vv}$ ), en by alle kerkraadsvergaderings kon 'n politieke kommissaris vanweë die owerheid sitting neem.

Die siening dat die volk of die gemenebes 'n gedoopte gemeenskap was en as sodanig een en eenvormig is, het veral geblyk uit die manier waarop die Hugenote wat in 1688 na die Kaap gekom het, ingeskakel is by die bestaande gemeenskap. Hulle is nié toegelaat om as ' $n$ aparte gemeenskap voort te bestaan nie, maar is kerklik, kultureel en andersins ingeskakel by die reeds bestaande gemeenskap. Dit was immers die beleid van die VOC om geen ander kerklike gemeenskap aan die Kaap toe te laat nie (JW Pont 1910: 102) en eers in 1779 word die Lutherane toegelaat om 'n eie gemeente met vrye godsdiensoefening aan die Kaap te vestig. So kon dit gebeur dat op 10 Desember 1780 ds A L Kolver as eerste Lutherse predikant aan die Kaap ontvang en bevestig kon word. Dié toegewing was waarskynlik moontlik omdat teen die einde van die 18 de eeu die verdraagsaamheidsbeginsel van die opkomende rasionalisme die Reformatoriese teokratiese siening van die organiese eenheid van volk en kerk geleidelik op die agtergrond gedruk het (J W Pont 1910: 111). Interessant is dat vir 'n tydlank nog, van 
die kant van die Hervormde Kerk, gevra is dat die owerheid nie Lutherane in die hoëre owerheidsposte moet aanstel nie. Met en na die eerste Engelse besetting van die Kaap het hierin ook 'n verandering gekom.

Samevattend kan gestel word dat vir die grootste deel van die periode van die Kompanjiesbewind die teokratiese visie van die gereformeerde kerkstaat, soos Haitjema dit noem, gehandhaaf was. Kerk en volk was prakties een en die gedoopte volk is regeer deur ' $n$ Christelike owerheid wat sorgvuldig na die belange van die kerk omgesien het. $\mathrm{Al}$ was die kerk, as gevolg van die ius patronatus, nie onafhanklik nie, was die kerk, naas die skool, die liggaam wat die sterkste godsdienstige en kulturele invloed uitgeoefen het of kon uitoefen. Dat dit nie altyd die geval was nie, was meer te wyte aan die predikante self as die strukture waarbinne hulle geleef en gewerk het (Hanekom 1959: $236 \mathrm{vv}$ ).

\section{PATRIOT-DENKE AAN DIE KAAP TEEN DIE EINDE VAN DIE AGTIENDE EEU}

'n Saak wat vir die doeleindes van hierdie ondersoek ook van belang is, is die indra van bepaalde denkbeelde uit die rasionahistiese Verligting wat veral vanuit Engeland en Frankryk die wêreld ingedra is. In Nederland het JD van der Capellen 'n demokratiese Patriotparty gestig teenoor die koningsgesinde party en sy aansluiting gesoek by die regenteoligargie wat Fransgesind was. Die belangrikste impuls vir die Patriotparty het gekom vanuit die geskrifte van die Engelse filosowe, Hobbes, Locke, Hume en Adam Smith en die Franse verwerking daarvan. Die Amerikaanse revolusie teen koning George van Engeland in 1776 het die bespreking van begrippe soos vryheid, natuurlike reg, die sosiale kontrak en die volkswil gestimuleer. Via Nederland het dié begrippe ook deurgewerk na die Kaapkolonie waar die VOC al meer besig was om die lojaliteit en tevredenheid van die inwoners te beproef. Die opvattings van die rasionele Verligtheid het direk in botsing gekom met die teokratiese opvatting van die organiese verbondenheid van volk, kerk en owerheid in 'n eenheidsgeheel (Leeb 1973: $149 \mathrm{vv}$ ). Dit is ook vanselfsprekend, want die Verligtheid aanvaar die volk en sy owerheid nie meer as 'n Goddelike instelling nie, maar die gevolg van die natuurlike en redelike insig van die mens. Volk en owerheid bestaan kragtens 'n kontrak of afspraak ('n gesekulariseerde verbond?) om in ' $n$ bepaalde staatsverband te leef. Daarmee vervaag die gedagte dat die owerheid ' $n$ roeping en taak het, deur God opgelê en soos in die geloofsbelydenis gestel. Al taak wat die owerheid het, is die salus 
publica en dít alleen op die horisontale vlak. Daarom wou die owerheid, in die dae van die Verligting, nie meer die Woord van God hoor wat vir hulle as riglyn dien nie en wou die owerheid ook nie meer beskermheer van die kerk wees sodat die kerk onbelemmerd sy taak kon uitvoer nie. In hierdie rasionalisme en sy siening van die gemeenskap is daar in feite geen plek meer vir die kerk nie omdat al die aandag op die diesseits gevestig is. Al plek wat die kerk nog het, is om deugsame, pligsgetroue landsburgers te kweek wat in gehoorsaamheid aan hulle owerheid sal lewe.

Die Patriot-gedagtes wat aan die Kaap deurgewerk het, deur kontak wat daar bestaan en geskep is met die Patriot-party in Nederland, vertoon 'n duidelike verwantskap met die Verligtheidsdenke. Dit blyk in 1779 uit die versoekskrif wat aan die Here XVII van die VOC gerig is en deur ' $n$ formele afvaardiging, 'Representanten van den geheelen Burgerstaat', na Nederland geneem is (Beyers 1967: 26-27). Die versoekskrif het nie alleen gevra dat daar 'n geskrewe grondwet vir die kolonie moes wees nie, maar dat die burgers ook die reg sou kry om wette te maak en toe te pas. Daarby is gevra dat die burgers sewe setels in die Raad van Politie sal kry en dat die burgers die reg moet ontvang om direk met die Here XVII te korrespondeer (Beyers 1967: 32-59). Eers in 1783 het die Here XVII grotendeels negatief op dié versoeke gereageer. Die versoek om sittingsreg in die Politieke Raad is afgewys, maar ses setels in die Raad van Justisie is aan die burgers gegee. Dié antwoord het geen tevredenheid gebring nie en in $\mathbf{1 7 8 5}$ het die Patriotte 'n nuwe petisie opgetrek en dit in die hande van vier verteenwoordigers geplaas wat dit nou, met verbygaan van die Here XVII, aan die Staten-Generaal moes voorlê. Dié saak het nie juis gevorder nie vanweë onderlinge geskille onder die Patriotte wat hulleself as "s Volks Representaten' aangesien het. Uiteindelik het die Staten-Generaal, na raadpleging met die Here XVII, die hele saak in die hande van die Goewerneur gelaat wat sommige van die klagtes tegemoetgekom het. Hierdie en ander kleiner en groter toegewings, het egter nie die Patriotte se verset teen die amptenare-regering en die monopolistiese ekonomiese praktyke van die VOC verminder nie (Boeseken 1944: 227). Die opvattings van die Patriotte oor die demokrasie en die opvattings oor selfregering het nie ' $n$ ruimte in die bestaande struktuur gevind nie en moes tot toenemende spanning lei, aangehelp deur die swak ekonomiese toestand van die kolonie (Beyers 1967: 237 vv). Hoewel die Patriot-beweging aanvanklik tot Kaapstad en omstreke beperk was, het die denkbeelde dwarsoor die Kolonie versprei en in 1796 verklaar die 
Nederlandse Kommissie van Buitelandse Sake, wat ondersoek moes ingestel het na die redes vir die oorgawe van die Kaap aan Engeland in 1795, soos volg (aangehaal deur Beyers 1967: 241).

'Ongelukkiglyk waren de gemoederen verdeeld, en terwyl dat in de Hoofdplaats zelve veele Inwoonders en de meeste Dienaars van de Compagnie den Prins van Oranje toegedaan waren, en selfs een sterke neiging, op eigenbelang gegrond, voedden voor de Engelschen, waren de Ingezetenen van het land, getergd door het misbruik van magt, al te dikwyls gepleegd door de Landdrosten en andere Dienaars van die Compagnie, en aangevuurd door het denkbeeld van America, zedert eenige Jaren bedagt geweest om het juk van de Compagnie af te schudden, en zich tot een vry en onafhanglyk Volk op te werpen. Eenige aanhangers dezer denkenswyze waren in de stad te vinden, doch de meeste bevonden zich in de districten van Graeffe, Regnet en Zwellendam.'

Die verwysing na Graaff-Reinet en Swellendam is vanselfsprekend, want daar het die burgers in die eerste helfte van 1795 die gesag van die Kompanjie afgeskud om hulleself onder die direkte regering van die Republiek van Nederland te plaas (Beyers 1967: 249). 'n Paar opvallende momente in hierdie gebeure, verdien ' $n$ bietjie meer aandag. In die eerste plek is dit opvallend dat die gedagte van die stem van die volk daar so 'n sterk rol gespeel het. Dáármee word teen staatsteorie dat die soewereiniteit of majestas van die gemenebes nié in die erfopvolgende vors gesetel was nie, maar in die volk self (Coertze 1938: $74 \mathrm{vv}$ ) na vore gebring. Daarmee het die gedagte saamgehang dat die hoofdoel van die gemeenskap on die enkeling die bevordering van die algemene welsyn was, 'n saak wat veral deur die Engelse filosoof, John Locke (1714), skerp gestel is in sy Two Treatises of Government en wat in die Patriot-beweging 'n soort vertrekpunt vir hulle denke was (vgl Van Eikema Hommes 1979: 138). In die verbygaan kan hier vermeld word, dat die doel van die gemenebes of staat die bevordering van die algemene welsyn, die salus publica, nie by die Voortrekkers ' $n$ rol in hulle grondwette gespeel het nie. Verder het hiermee die sterk beklemtoning van vryheid saamgehang, wat as godsdienstige èn burgerlike vryheid aangedui is en wat as ' $n$ aangebore, natuurlike reg in die konteks van die Patriot-denke beskou is (Beyers 1967: $222 \mathrm{vv}$ ). Dit alles word saamgevat in die gedagte dat die regeerders van die volk, deur die vrye stem van die volk verkies, die representanten van die vrye burgers is (Beyers 1967: 229). Alleen deur so 'n struktuur kan daar ware vryheid 
vir die landsburgers wees en kan die misstande en uitbuiting wat die resultaat van die amptenare-regering van die Kompanjiesbewind was, uit die weg geruim word. As gelet word op die situasie wat grotendeels onbevredigend was, wil dit voorkom asof die Patriot-denkbeelde eerder gebruik is om van die misstande ontslae te raak as dat dit, soos in Europa, 'n totaal nuwe opvatting van die struktuur van die samelewing, die regte en vryhede van die mens was wat hier uitgedra is. Die Patriotdenke in Nederland en die voorbeeld van die suksesvolle Amerikaanse revolusie is gebruik om ook in die Kaapkolonie beter lewensvoorwaardes te kry.

Dit is duidelik dat die slagkrete wat in die Kaapkolonie gebruik is, grotendeels afkomstig is uit die Patriotparty in Nederland. Leeb (1973: 157) karakteriseer die Patriotdenke as hy stel:

$\therefore$ they are liberty-loving, rule themselves directly in popular assemblies, and are all armed and equal in participation. They are only ruled by those they freely choose and can freely depose.'

Dat die Nederlandse Patriotte se verbondenheid met Franse opvattings óók na die Kaap deurgewerk het, blyk daaruit dat in Graaff-Reinet die burgers hulle regeerliggaam 'n Nasionale Konvensie genoem het en dat die representante van die volk die driekleur-kokarde gedra het (Beyers 1967: 246). Opvallend is ook dat in Graaff-Reinet, direk teen die opvattings van die ouer teokratiese struktuur, 'n duidelike skeiding tussen die burgerlike regering èn die kerk deurgevoer is. Dié opvatting word later ook by De Mist, die Kommissaris-Generaal van die Betaafse Republiek, aangetref wanneer hy dié nuwe denke in die Kaapse samelewingstruktuur indra. Die interessante ontwikkeling aan die Kaap het met die eerste besetting van die Kaap deur Engeland wat op 16 September 1795 begin het, nog ' $n$ nawerking gehad, maar die georganiseerde Patriot-beweging verdwyn dan van die toneel. Dit het egter nié beteken dat daarmee die ideaal van vryheid en sommige van die opvattings van die Patriotte terselfdertyd verdwyn nie. Beyers (1967: 281) stel selfs: 'In die Groot Trek en lank daarna, selfs nadat die Patriotte-beweging as sodanig nie meer bestaan het nie, sien ons die onmiskenbare spore daarvan.' Daarom verwys hy na Gerrit Maritz as "n allesins waardige Patriot' (Beyers 1967: 285), Erasmus Smit val vir hom ook in daardie patroon (Beyers 1967: 286), asook president Paul Kruger wie se familie betrokke was by die Patriot-beweging (Beyers 1967: $288 \mathrm{vv}$ ). 'n Tipiese kenmerk van die Patriotdenke, wat volgens Beyers deurwerk na die Voortrekkers, is die beklemtoning van die volk as die omskrywing van 
die gemeenskap, as die geheel wat self die toekoms moet en kan bepaal. Dié opvatting wat veral deur die groot Patriotleier in Nederland, J $\mathrm{D}$ van der Capellen op skrif gestel is, was ook in Suid-Afrika bekend. Beyers (1967: 212) wys daarop dat die Kaapse Patriotte in verbinding met Van der Capellen was wat veral in sy pamflet, Aan het volk van Nederland, groot invloed in die Patriotbeweging gehad het. Van der Capellen se opmerking in die genoemde pamflet dat God die God van vryheid is wat sy volk uit die slawehuis van Egipte gelei het om hulle vryheid te skenk, laat dink aan soortgelyke argumente by die Voortrekkers. Die opvallende is egter dat in die periode waar die regte van die mens sterk op die voorgrond staan en die enkeling se waarde beklemtoon word, hier nog vasgehou word aan die volk-begrip (Leeb 1973: 158-159). Die vraag bestaan egter of hierdie Voortrekker- en Afrikanerleiers gedra was deur die opvattings van die Patriotte en of daar nie ander elemente is wat 'n groter bydrae tot hulle denke gelewer het nie. In hierdie verband is dit ook belangrik om op die belangrike werk van Murray te wys wat veral aan De Mist se opvattings aandag gegee het (Murray s a: 137). Ten opsigte van hierdie periode kan verder daarop gewys word dat die kerk in die Kaapkolonie feitlik geen rol ten opsigte van die Patriotbeweging gespeel het nie. Om die oorsake daarvan na te gaan, is nie nou hier ter sake nie. Die feit kan slegs gekonstateer word dat uit die briefwisseling wat vanuit die Kaapse gemeentes met Nederlandse instansies gevoer is (Spoelstra 1906: 329-586) vasgestel kan word dat juis dié dinge wat in Graaff-Reinet en Swellendam die inwoners intens besig gehou het, by die kerk verbygegaan het. Vandaar dat Murray (s a: 115) stel:

'Yet De Mist found the church uncentralised and the congregations unadapted to meet the demands its flocks made on it.'

So gebeur dit dat juis in hierdie tyd waar nuwe gedagtes sterk na vore kom en selfs die posisie van die kerk in die gemeenskap ter sprake is, die kerk self swyg. Daaruit kan afgelei word dat in die kerk sélf nie meer 'n duidelike begrip van die plek, posisie en taak van die kerk in die volk, in die gemenebes èn die openbare lewe, was nie. Dit het vir'n deel seker saamgehang met die feit dat die nuwere gedagtestromings ' $n$ ander koers geloop het en in die kerk nie besef is dat hierdie sekulariserende opvattings in botsing met die Reformatoriese waarhede was nie. Die laat 17de- en 18de-eeuse teologie in Nederland wat al sy aandag toegespits het op die heilsekerheid van die gelowige, het die groot, omvattende teokratiese visie van die Calvinistiese teologie op die ag- 
tergrond gelaat en vergeet. Die strewe na heilsekerheid en heiligheid het meegebring dat die kerk sy taak en opdrag, om juis in die wêreld vormend en toekomsgerig die Woord te verkondig, verwaarloos het en as gevolg daarvan grotendeels weerloos teen die nuwe denke was.

Miskien kan hier net daarop gewys word dat verskillende skrywers wat oor die staatsopvattings van die Voortrekkers geskryf het, baie moeite gedoen het om aan te toon dat die Voortrekkers, vir 'n baie groot deel afkomstig uit die distrik Graaff-Reinet, grotendeels draers van die opvattings van die Patriotte en effens later De Mist, was (Gey van Pittius 1941: 9 vv; Wypkema 1939: 155 vv; Beyers 1967: 281 vv; Murray s a: 137). Dit staan vas dat baie van die formele strukture wat die Voortrekkers ingestel en gehandhaaf het, aan De Mist en sy vormgewing te danke was (Wypkema 1939: $318 \mathrm{vv}$ ) en dit is óók duidelik dat in die Oorvaalse, met die opstel van die grondwette vir die ZAR, daar 'n groot afhanklikheid van Nederland vasgestel kan word. Dit is egter 'n vraag of hierdie afhanklikheid van Patriot-opvattings en De Mist se reëlings aan die Kaap nie té sterk gestel word nie en dat vergeet ivord van die Calvinisties-teokratiese opvattings wat ook baie lewendig onder die Voortrekkers en hulle navolgers was. Daarom lyk dit noodsaaklik om ook vervolgens aandag te vra vir die godsdienstige opvattings, soos dit blyk uit die grondliggende reëlings wat die Voortrekkers èn hulle opvolgers getref het vir die ordening van hulle maatskappy of gemenebes.

\section{DIE VOORTREKKERS SE VORMGEWING VAN HULLE MAATSKAPPY}

Die Voortrekkers wat in die jare 1835, 1836 en daarna die Kaapkolonie verlaat het, het dit gedoen om in die leë binnelande van Suid-Afrika (Du Plessis 1943: $116 \mathrm{vv}$ ) vir hulleself ' $n$ vrye vaderland te soek waar hulle hulself na hulle eie insigte kon regeer. Met die Trek het die Voortrekkers doelbewus hulle Britse onderdaanskap (Du Plessis 1943: $226 \mathrm{vv}$ ), hulle lidmaatskap van die kerk in die Kolonie en die struktuur van die gemeenskap in die Kolonie agtergelaat (Gey van Pittius 1938: $44 \mathrm{vv}$ ). Die Voortrekkerideaal was om 'n eie maatskappy of gemenebes na hulle eíe insigte te bou. Om dié vormgewing na te gaan, kan op die volgende gelet word, sonder om in te veel besonderhede in te gaan.

Op 2 Desember 1836 het die Voortrekkers onder die leiding van kmdt Hendrik Potgieter en Gerrit Maritz by Blesberg 'n eerste Burgerraad gekies. Daarvolgens is Maritz as president en Potgieter as militêre hoof 
gekies, ondersteun deur 'n raad bestaande uit nog vyf persone (Schoon 1897: 8).

Hierdie Burgerraad is deur een algemene volkstem verkies en die taak van hierdie Rechters was om 'voor het algemeen best en vrede' te sorg. Dié doel sou bereik kon word sodra ' $n$ algemene vergadering die nodige wette en reglemente opgestel het. Opmerklik is die formulering (Preller 1920: I, 298):

'Welke hoofden Hun Edelens hebben onderworpen, om solemeelijk met Eede te beloven ... waarbij ter andere zijde de Gemeene Manne, uitmakende het Volk, ook met Eede beloofd hebbende zich getrouw en vreedzaam te onderworpen aan den uitspraak en bevelen van bovengemelde Hoofden.'

Dit was dus die eerste poging van die Voortrekkers om aan hulle maatschappij of gemenebes 'n duidelike vorm te gee. Hierdie eerste Volksraad of Burgerraad het betreklik kort gefunksioneer. Op 17 April 1837 is by Vetrivier weer ' $n$ algemene of volksvergadering gehou, en daar is opnuut leiers gekies. By hierdie geleentheid is Piet Retief, wat toe met sy trek teenwoordig was, as goewerneur of president gekies en Gerrit Maritz tot magistraat en voorsitter van die Burgerraad. Na Retief se verkiesing as goewerneur het hy ook aandag aan die kerklike sake in die maatskappy gegee. Dit was nodig om die plek van onze Reizende Gereformeerde Kerkgemeente in de Woestijn te bepaal en daarvoor is ' $n$ algemene volksvergadering gehou (Schoon 1897: 22). Op 21 Mei 1837 is Erasmus Smit, toe by die laer van die Vetrivier, as predikant bevestig. Hy teken daaroor aan (Schoon 1897: 22-23):

'De Leeraar werd heden, door eene aanspraak van den Gouverneur, $P$ Rietief, aan de gemeente voorgesteld. $Z$ ijn Ed betuigde voor God, dat hij nięts gevonden had, dat hem het kon beletten, om den wel Eerw Heer Erasmus Smit als den eersten Leeraar voor de reizende gemeente der Gereformeerde Kerk naar Port Natal aan te stellen, enz.'

Op grond van die aanstelling deur die goewerneur het Erasmus Smit die bevestigingsformulier gelees, self daarop geantwoord en so as bevestigde predikant sy dienswerk begin.

Die eerste kerkraadslede is, na goedkeuring van die name deur die goewerneur, en nadat hulle deur die lot verkies is uit die tien goedgekeurde name, op 3 Desember 1837 deur Erasmus Smit bevestig. 
So is die selfstandige kerk in die onafhanklike Voortrekker-maatskappy opgerig deur die optrede en goedkeuring van die bestaande owerheid. Hieruit is dit baie duidelik dat die Voortrekkerkerk geen organisatoriese band met die kerk in die Kaapkolonie gehad het nie. Dit sou ook, in die lig van die Voortrekkers se opvattings in hierdie verband, nie moontlik gewees het nie.

Die Burgerraad het inmiddels na die verkiesing van 17 April 1837, 'n 'grondwet' opgestel en die artikels is op 'n vergadering, wat op 6 Junie gehou is, gelees en na enkele wysigings goedgekeur (Schoon 1897: 24).

Dit is belangrik om op Erasmus Smit se mededelings in hierdie verband te let. Hy skrywe in sy Dagboek:

'Hij (dit is: Retief - ADP) deed aan de Gemeente des ganschen volks, als de door hunne stem verkozene Gouverneur en Opperbevelhebber van het algemeene leger, een korte inleidende aanspraak, betrekkelijk het oogmerk van deze plechtige algemeene volksvergadering.'

Nadat Erasmus Smit in gebed voorgegaan het, is die 'grondwet' voorgelees en goedgekeur. Daarmee is die grondslag vir die nuwe gemenebes gelê en is die naam van die Voortrekker-maatskappy ook vasgestel, naamlik De Vrije Provincie van Nieuw Holland in Zuid Oost Afrika.

Erasmus Smit vervolg dan sy relaas:

'Voorts gingen wij over tot de stellingen van de formulieren van de plichtmatige en plechtige heilige eeden, te zweren op dezen dag....

Een formulier voor Zijne Excellentie (dit is die goewerneur ADP); een voor den wel Ed. Heer G Maritz, President-Rechter van den Raad van Policie, en voor andere Ed. Heeren van den voornoemden Raad; een voor den Leeraar der Gereformeerde Kerk, den wel Eerw E Smit; een voor de ... Vrederechters; en een voor al het volk.'

Die 'grondwet' self het maar uit 9 artikels bestaan en was hoofsaaklik daarop gemik om sowel die grense as die eenheid van 'onsen Vereenigde Maatschappij' te beklemtoon. Dit blyk veral uit die volgende bepalings (Preller 1920: 300-301):

'1. Wij die gerefformeerde Leedematen zijn begeerig dat een eider, geenen uitgezondert, zal moeten afwijken van allen den sendelings genootschap van Engeland, en verder daarvoor opentlijk bedanken. 
3. Dat allen die zich tegens deze Resolutie opbeuren, door deezen vereenigde Laager buijten de Maatschappij zullen moeten worden gesteld.

4. Verder dat allen diezulken, die tegens deezen gemaakte resolutie zigt stelt, niet zullen worden toegelaaten om binnen de Limieten van de Vereenigde Lager in het Bedoelde land zich needer te zetten, te jagten of eenigen ander dat op of in ons bedoelde land zijn, op straffe als volgt.

9. En zeg verder, dat allen personen die onzen vereenigde Laager mag koomen te volgen, om zig bij onze Maatschappij te stellen, zich dadelijk zal moeten verplichten om humen Eed af te leggen en dan ten anderen die zig van desen Laager afschijt en verlaat, zal binnen de twee maal 24 uren zorgen om hunne schulden allen af te betaalen of hunne goederen zullen in beslag worden genomen en verkogt worden, totdat de schuld en koste voldaan zijn.'

Dit was dus maar 'n raamwerk van 'n grondwet, want oor die pligte en funksies van die owerheidspersone, van die Politieke of Burgerraad en derglike word niks gesê nie. Dit sou eers aandag kry as die 'Bedoelde Land' bereik is. Tog kan daar uit die daaropvolgende gebeurtenisse 'n verdere indruk gekry word oor hoe die Voortrekkers die struktuur van hulle maatskappy verstaan het.

Die eerste is dat Erasmus Smit met Retief onderhandel het en hom daarop gewys het dat hy in sy ampseed niks vermeld het dat hy hom verbind aan die geloofsbelydenis van die 'Gereformeerde Nederduitsche Kerk' nie. Erasmus Smit teken aan (Schoon 1897: 25):

'Het gelukte den Leeraar, dat Zijne Excellentie aan deze voordracht gehoor verleende; en zich ook door dit punt, met eede, bij de Geloofsbelijdenis der voornoemde kerk zou laten verbinden, met bijvoeging dat Zijn Ed. in alles wilde instemmen, wat tot heil van't volk en de Kerk kan verstrekken, volgens den inhoud van artikel 36 onzer Geloofsbelijdenis.'

Dit het daartoe gelei dat op Sondag 11 Junie 1837 Retief in 'n godsdiensoefening sy ampseed in hierdie sin uitgebrei het. Smit vermeld dat hy die Bybel oopgeslaan het op die plek waar die NGB en die Heidelbergse Kategismus voorgekom het. Nadat Retief sy hand daarop gelê het, het hy knielende voor die spreekplaats wat gedien het as preekstoel, die volgende eed afgelê (Schoon 1897: 26): 
'Ik, Pieter Retief, door de volksstem wettig gekozen tot hun Gouverneur en Opperhoofd des Algemeenen Vereenigden Legers, zweere thans mede plechtig voor God Almachtig, dat ik, als de door het volk verkorene gouverneur (en al die Gouverneuren in der tijd, die na mij deze vereenigde maatschappij zullen komen te regeeren), de Christelijke Geloofsbelijdenis, naar den inhoud van artikel 36, met de aankleving van dezelve, der Nederduitsche Gereformeerde Kerk zal protecteeren en beschermen; en dat ik in mijn Gouvernement geen Beambte zal toelaten in de Kerkelijke en Burgerlijke Regeering, als die lidmaten zijn der voormelde Gereformeerde Kerk en van hunne goede getuigschriften voorzien zijn. Daartoe helpe mij God Almachtig.'

Dit is interessant dat Erasmus Smit, nadat die ampseed afgelê is, die taak van die goewerneur as volg omskryf het (Schoon 1897: 27):

'... onze voormelde Kerk en Belijdenis, met aankeuring van dezelve, onder Uw Wel Ed. Regeering te zullen protecteeren, voorstaan, beschermen en helpen, in goeden stand en bij de zuiverheid en eenigheid te houden.'

So het die Voortrekkers, terwyl hulle nog getrek het, al die grondslae gelê vir hulle bestaan as ' $n$ onafhanklike, vry volk in die binneland van Suid-Afrika.

Die Voortrekkers, onder leiding van Piet Retief het na die Vetrivierbyeenkoms na Natal getrek, terwyl Potgieter en Uys nog eers 'n tweede strafekspedisie teen Silkaats sou onderneem (Du Plessis 1943: 122). Eers na die moord op Retief, die Slag van Bloedrivier en ander optrede teen die Zoeloes, is op 14 Mei 1839 ' $n$ vredesooreenkoms met die Zoeloes onderteken en kon dié deel van Natal wat die Voortrekkers kragtens die Retief-Dingaan-traktaat en wat later bygevoeg is, in besit neem. Deur verdrag en verowering het die Voortrekkers nou 'n vaderland bekom (Du Plessis 1943: 140).

In Natal, waar die moontlikheid van 'n permanente vestiging nou werklikheid geword het, is weer 'n grondwet opgestel wat as titel dra: Instructiën voor den Raad van Representanten van het Volk (Preller 1924: XII-XVI). Presies wanneer hierdie Grondwet opgestel is, is nie duidelik nie. Die moontlikheid dat dit reeds betreklik vroeg in 1838 opgestel is, lyk waarskynlik (Du Plessis 1943: 163). As basis is die 'demokratiesgetinte grondwet deur Janssens en De Mist aan die Kaap ingestel, tot rigsnoer geneem....' (Du Plessis 1943: 162). 
Hierdie grondwet het voorsiening gemaak vir 'n Raad, bestaande uit 24 lede, gekies deur die stemgeregtigde burgers. Opvallend is dat nou aan hierdie Volksraad alle uitvoerende, wetgewende en regterlike magte gegee is. Daar was dus nie meer so iets soos 'n hoof-uitvoerende beampte soos Retief nie. Die Volksraad sou nie onbeperkte gesag hê nie, want volgens die opvattings van die Voortrekkers het die soewereine mag by die volk berus en was die Volksraad inderdaad die representanten van het Volk. Daarom kon die burgers, deur middel van memories en versoekskrifte, hulle wense aan die raad stel.

Aanvanklik het hierdie Volksraad alleen die Natalse deel van die Voortrekker-maatskappy bestuur. Op 16 Oktober 1840 is egter 'n algemene vergadering in Potchefstroom gehou waar die Natalse Volksraad deur AWJ Pretorius en GR van Rooyen verteenwoordig is. Daar is besluit dat Pietermaritzburg die hoofstad van die Voortrekkerrepubliek en die setel van die Volksraad sou wees. Die Oorvaalse Voortrekkers sou deur drie verteenwoordigers van die Potchefstroomse Adjunkraad, wat uit 12 lede bestaan het, verteenwoordig word. Die Adjunkraad sou as ' $n$ komitee van die Volksraad dien en sy besluite moes deur die Volksraad goedgekeur word. Verder sou Pretorius optree 'als hoofdbestierder over de gehele volksplanting in het distrekt Natalis' en kmdt A $\mathrm{H}$ Potgieter as 'bestierder' van die Potchefstroomse distrik wat ook Winburg ingesluit het (Du Plessis 1943: 169). Uit hierdie reëlings het in 1844 die Drie-en-dertig Artikels ontstaan wat in die Oorvaalse gegeld het nadat Natal deur Engeland geannekseer is. Hierdie artikels toon ' $n$ duidelike verwantskap met die Natalse bepalings oor die regspleging. Hierin het die Voortrekkers aangesluit by die reëlings wat De Mist neergelê het vir die Kaapse buite-distrikte (Du Plessis 1943: 172).

In die Instructiën wat as grondwet gedien het, is die kerklike sake ook gereël (Preller 1924: XIII):

'14. De Raad zal ook vlytig moeten naarkomen dat in deze Maatschappy, de Hollandsche Gereformeerde Kerk, ten allen tyde geprotecteerd zal worden, en erkend blyven voor de hoofd-kerk derzelve.'

Dit het beteken dat die hooflanddros die finansies en administrasie van die kerk moes nagaan en daaroor verslag moes doen. Daarby het die Volksraad ook kerkraadslede en predikante aangestel. So word op 3 Januarie 1840 David Fransooijs Jacobs van Suikerbosrand as ouderling en katkiseermeester vir die gebied wes van die Drakensberge aangestel (Preller 1924: 27). In dieselfde vergadering word besluit: 
'Is voortgebragt door enige leden van den Raad, om den heer Lindley aan te stellen als Predikant onder ons. Door de gesaamentlijke leden goedgekeurt, mits hy zyn documenten toonen zal voor de volgende vergadering en dat hij onze grondstelling van de Gereformeerde Kerk aanneemt voor degene die hem vorkiest. Echter zal den heer Smit blyven bestaan als leraar voor de geene die hem verkoozen heeft, onder protectie naar inhoud van zyn aanstelling.'

So stel die Volksraad self 'n tweede predikant aan, waarskynlik om die besware tegemoet te kom van diegene wat van die begin af nie met Erasmus Smit se bediening tevrede was nie (Preller 1924: 31). Nadat Lindley sy eed van trou aan die Volksraad afgelê het en daar aan die volk kennis gegee en sy stukke nagegaan is, is hy op 16 Januarie 1841 aangestel. Daar is bepaal dat, indien nodig, sy traktement deur die Volksraad betaal sal word (Preller 1924: 91-92).

Dit is interessant om vas te stel dat die Volksraad op 7 Maart 1840 Erasmus Smit sonder meer emeriteer (Preller 1924: 42), op 4 September 1840 hom ernstig vermaan oor 'zijne aanstotelijk gedrag' (Preller 1941: 75) terwyl hy in April 1843 de facto deur die Volksraad onder sensuur geplaas word deurdat hy verbied word om die sakramente te bedien (Preller 1924: 242).

Hieruit blyk dat die Volksraad sonder meer op bepaalde punte intree in kerklike sake en doen wat in werklikheid die taak en opdrag van die kerkraad is. Omdat die kerk 'staatskerk' is, het die Volksraad so opgetree sonder dat iemand daarteen enige besware gehad het. Daarby moet in ag geneem word dat die kerklike gewoonte, soos die Voortrekkers dit geken het, so 'n optrede grotendeels gebillik het. Vanaf 1652 was die kerk in die Kaapkolonie, kragtens die ius patronatus nooit werklik 'n selfstandige kerk nie, maar slegs 'n onderdeel van die VOC. Dit was die VOC, as landsowerheid, wat predikante aangestel, besoldig, geplaas en verplaas het en selfs afgesit of uit die Kolonie weggestuur het.

Hoewel á Brakel (1736/I: 686) die selfstandigheid van die kerk sterk beklemtoon het, het die Voortrekkers dit in die Kaapkolonie nooit so ervaar nie. Daarom was dit vir hulle vanselfsprekend dat in hulle gemenebes, wat so sigbaar 'n organiese eenheid was, die Volksraad sou inmeng in kerklike sake as dit om die welwese van die kerk gaan.

Voordat aandag gegee word aan die strukturering van kerk en maatskappy in die Oorvaalse gebied, kan daar eers aandag gegee word aan 
'n beoordeling van die wyse waarop die Voortrekkers die taak aangepak het.

\section{BEOORDELING VAN DIE WYSE WAAROP DIE VOORTREKKERS HULLE MAATSKAPPY INGERIG HET}

Bo en behalwe die bogenoemde gedagtestrominge en opvattings wat op die Voortrekkers ingewerk en waarmee hulle klaarblyklik bekend was, moet daar ook en veral rekening gehou word met die godsdienstig-teologiese literatuur waarmee die Voortrekkers bekend was. Onder die geskrifte van die oude schrijvers of die auteurs moet veral die werk van Wilhelmus á Brakel belangrik geag word. Sy omvangryke werk, Redelyke godtsdienst, in welke de goddelyke waerheden des genadenverbondts worden verklaart, tegen partyen beschermt en tot de practyke aengedrongen, wat in 1700 die eerste maal in Rotterdam die lig gesien het en daarna voortdurend herdruk is, het onder die Voortrekkers as 'n soort dogmatiek-handboek gegeld. Afgesien van die katkisasieboeke van Abraham Hellenbroeck en Aegidius Francken, was dit die belangrikste sistematiese uiteensetting van die inhoud van die Skrif en die hervormde kerkleer wat hulle gehad het. Dat á Brakel deur die Voortrekkers geraadpleeg en gevolg is, blyk baie duidelik as gelet word op die voorskrifte wat á Brakel gee vir die aflê van 'n gelofte en die wyse waarop die Voortrekkers in Desember 1838 die gelofte afgelê het (vgl á Brakel 1736/II: 508 vv). Dit lyk volkome vanselfsprekend dat á Brakel, juis by die vormgewing van die Voortrekkers se maatskappy of gemenebes óók geraadpleeg sou word. As die moeite gedoen word om á Brakel se omvangryke werk deur te worstel, en dit wil voorkom asof dit nog nie vantevore in ons kerklike kring aangedurf is nie, word ' $n$ hele reeks van Voortrekker-opvattings meer verstaanbaar (Wypkema 1939: 454).

Wilhelmus á Brakel, gebore in Leeuwarden in 1635 het aan sowel die Groningense as die Utrechtse Universiteite gestudeer en daarna in verskillende Friese gemeentes gestaan. In 1683 word hy na Rotterdam beroep waar hy nog 28 jaar as predikant gewerk het. In 1711 is hy in Rotterdam oorlede en daar begrawe. á Brakel word normaalweg gereken tot die streng Calvinistiese party in die Nederlandse kerk. Hy is nogal beïnloed deur die Nadere Reformasie, wat veral blyk uit sy sedeleer en deur die praktiese wyse waarop hy die uiteensetting van die kerkleer klee. Dit was verstaanbaar dat á Brakel se geskrifte tot 
vandag toe, veral in Nederland, herdruk en gelees word (De Bie en Loosjes s a/I: 563-571).

Hoewel á Brakel nie 'n aparte beredenering gee van sy siening van die gemenebes en hoe dit gestruktureer moet word nie, is dit tog uit sy werk af te lei dat hy die teokratiese visie ten opsigte van die gemenebes, soos dit in Artikel 36 van die NGB gegee word, handhaaf. Dit is seker vanselfsprekend, want in sy leeftyd het die publieke proklamasie van die 'Gereformeerde kerkstaat' plaasgevind. Daarby word á Brakel se opvattings baie sterk bepaal deur die verbondsgedagte wat by hom die basiese struktuur is van die hele verhouding van God en mens (á Brakel 1736/I: Hoofstukke 12 en $16 \mathrm{vv}$ ). Tog is die verbond by á Brakel nie die grondstruktuur van die gemenebes nie, maar van die kerk, hoewel die feit dat die lede van die volk gedoopte lidmate van die kerk is, meebring dat die owerheid in die gemenebes ' $n$ omskrewe taak ten opsigte van kerk èn volk het.

Wat die kerk betref, stel á Brakel dat die genadeverbond èn die kerk feitlik sinonieme is (á Brakel 1736/I: 553), want 'dese eene kerke bevat in sig alle Uytverkorene van den beginne des werelts geroepen en tot het eynde des werelts nog te roepen. Dese zyn een eygen volk van Christus.' Die kerk waaraan die gelowige in die tyd behoort is die strydende kerk en daarvan sê hy: 'Dese kan men aenmerken of in haer geheel, soo alsse verspreyt is over de geheele wereldt ofte in de particuliere vergaderingen van een Landtschap, Stadt ofte Dorp. Soo segt men de kerke van Engeland, van Nederlandt, van Rotterdam' (á Brakel 1736/I: 547).

Belangrik vir die optrede van die Voortrekkers in die organisering van ' $n$ selfstandige kerklike gemeenskap in hulle maatskappy is die aanwysing wat á Brakel in Hfstk 28, bladsy 640 gee as hy stel: 'Als in een plaetse nog geene Kerken en Leeraren zyn, maer Kerken vergadert worden, dan is nodig dat van andere daer Leeraers gesonden worden, ofte uyt geloovige Leden van die Kerke Leeraers gemaekt worden' (my beklemtoning). Dat sodanige optrede nie kerkskeurend ten opsigte van die ware kerk is nie, word deur á Brakel beklemtoon met sy stelling dat die eenheid van die kerk nie bepaal word deur die gebondenheid van alle kerke aan ' $n$ bepaalde plek soos Jerusalem of Rome of enige ander plek nie. Die eenheid van die kerk sê á Brakel (1736/I: 556), ' . . is niet ten opsigte van hare uytwendige vertooninge in de wereldt, ... maer ten opsigte van hare nature ende wesen ... ten opsigte van de selfde leere der onveranderlyke waerheyt, van het selfde geloove, van de selfde Geest, van de selfde Heyligheyt. Dese eenheyt wort getoont in 
hare t'samenkomste tot het gehoor van Godts Woordt ende het gebruyk der heiliger Sacramenten...'

Die kerk staan in die gemeenskap, is tot in 'n hoë mate die gemeenskap en was in die Voortrekkergemeenskap waar almal gedoopte lidmate was, identies met die gemeenskap. Dié kerk wat as vanselfsprekend volkskerk en bevoorregte kerk was, het dieselfde posisie wat die kerk in die tyd van die Kompanjiesbewind gehad het, in die Voortrekkergemeenskap gekry. Die feit dat in die Voortrekkergemeenskap die burgerlike owerheidspersone en die kerklike ampsdraers dikwels dieselfde was, het ook daartoe bygedra dat die grense nie baie duidelik getrek is nie.

Opvallend is dat in die strukturering van die Voortrekkergemeenskap by Vetrivier, ' $n$ onderdeel van die verbondsmatige teokrasie sterk na vore gekom het wat veral in die Hugenote se versetsliteratuur beklemtoon word. Dié opvattings het aangesluit by Calvyn se stelling dat die volk die reg het om van die vors te verwag dat hy God se wet sal handhaaf en in belang van die volk sal regeer. Daarteenoor het die vors die reg op die gehoorsaamheid van sy onderdane. Hier kom die gedagte van 'n verbond of verdrag tussen vors en volk na vore en dié saak word veral deur Calvyn se opvolgers verder uitgewerk (vgl De Visser 1926: 81). Dié nadere presisering word veral gevind in die Franco-Gallia van $\mathrm{F}$ Hotoman van 1573, die de iure magistratuum van $\mathrm{T}$ Beza van 1574 en die Vindiciae contra tyrannos wat in 1579 gepubliseer is en waar die skrywer as Stephanus Junius Brutus aangedui word, terwyl die skrywers waarskynlik Hubert Languet en Du Plessis-Mornay is. Hierdie gedagtepatroon was nie alleen bekend aan die Hugenote wat in 1688 na die Kaap gekom het nie, maar dit het ook deur middel van die sewentiende-eeuse juris, Hugo Grotius, wat regsadviseur van die VOC was, na Suid-Afrika deurgewerk (vgl Murray 1966: 313).

Die elemente van die aflê van 'n eed deur die verkose owerheidspersone èn die eed wat die volk aflê volgens die Vetrivier-grondwet van 1837, dui op die verbond-kontrak-karakter van die verhouding van owerheid en volk. Nog sterker kom dit uit in die ampseed van Retief waar, met verwysing na Artikel 36, dit duidelik is dat hy as goewerneur daar is ter wille van die volk om die Wet van God te handhaaf en so die belang van hierdie christelike volk te dien. Dit word onderstreep deur die feit dat Retief ook belowe dat slegs lidmate van die erkende kerk as burgerlike of kerklike ampsdraers aanvaar sal word. As Erasmus Smit ná Retief se eed-aflegging stel dat Retief as goewerneur die kerk moet beskerm en behou in die suiwere leer, klink dit byna soos 'n sitaat uit 
die Vindicae waar oor die taak van die pius magistratus of owerheidspatroon gesê word (Laski 1972: 218):

'... but it is the duty of all kings, princes and magistrates, not only to amplify and extend the limits and bounds of the church in all places, but also to preserve and defend it against all men whatsoever.

... therefore ought they to employ the utmost of their ability to reform and wholly to restore that which they hold to be the pure and Truly Christian church, to wit, ordered and governed according to the direction of the Word of God.'

Dit, net soos Retief se ampseed, lê volkome binne die visie van die Calvinistiese teokrasie waar volk, kerk en owerheid 'n vanselfsprekende en organiese eenheid is. Die siening kan nie sonder meer as 'Ou Testamenties' getipeer word as sou dit net 'n beperkte geldigheid gehad het nie. Die Voortrekkers het onder andere by á Brakel geleer dat die Skrif ' $n$ eenheid is en dat die Ou Testament nie teen die Nuwe Testament afgespeel kan word nie (vgl á Brakel 1736/III: 1-115). Daarom is dit tog ' $n$ vraag of Erasmus Smit, Gerrit Maritz en Piet Retief inderdaad as verteenwoordigers van die Patriot-denke aangedui moet word. Dit lyk in die lig van die Voortrekkers se grondwette nie waarskynlik nie. Immers in die denke van die Verligtheid word die algemene welsyn, die salus publica, suiwer diesseitig verstaan, terwyl dit juis in Retief se ampseed duidelik word dat die owerheid, gebind aan Skrif èn belydenis, ook ' $n$ taak het tot kerstening van die kultuurlewe van die volk.

Dit is interessant om daarop te wys dat in die Voortrekker-grondwette dit die twee partye die volk en die owerheid is wat 'n verbondkontrak sluit. Dit is in teenspraak met die opvattings van die 18deeeuse Verligtheid waar dit nié om die volk gaan nie, maar om die regte en vryhede van die enkeling-mens. Die voorbeeld vir so ' $n$ verbondkontrak tussen koning (= owerheid) en volk word nie net in die $\mathrm{Ou}$ Testament gevind nie (II Kon 11: 17), maar ook in verskillende ander situasies. Dat die volk in die denke van die Voortrekkers so 'n belangrike plek inneem, dank die Voortrekkers grotendeels aan die feit dat hulle, geleer deur á Brakel, vasgehou het aan die leer van die verbond, soos dit in die Skrif voorkom. Terselfdertyd is dié opvatting waarskynlik versterk deur die feit dat De Mist óók, in sy anti-revolusionêre denke, die volk as die essensiële politieke grootheid sien (Murray: 23-24). Hoewel Coertze korrek is as hy stel dat die Voortrekkers die 
majestas van hulle maatskappy in die volk gesetel het, was hier vir die Voortrekkers tog iets meer op die spel as die beginsel van volksoewereiniteit wat in die staatkundige denke van die Verligtheid so ' $n$ groot rol gespeel het. Dit is waar dat die Representanten van het Volk, volgens die Grondwet van 1838, in hulle ampseed verklaar dat hulle hulle taak sal uitvoer '... niets anders in't oog hebbende, dan om't algemeen best en wilzijn te bevorderen...' (Preller 1924: 304). Die vraag is egter of hierdie formulering, wat so geliefd was in die Patriotdenke, die draagkrag en betekenis gehad het wat die rasionalistiese Verligtheidsdenke daaraan gegee het. By die Voortrekkers is, volgens die Grondwette wat nagegaan is, die volk eerder aanduiding van die Bybelse verbondsvolk as die gesekulariseerde demos wat in die demokratiese staatsopvatting na vore kom. Die feit dat die Voortrekkers van die begin af net één kerk in hulle midde toelaat en dit ook in Artikel 1 van die Vetrivier-grondwet stel, dui daarop dat hulle baie meer in terme van die Calvinistiese teokratiese staatsopvatting gedink het, aan 'n Christelike owerheid gebind aan Skrif en belydenis.

Dit is waarskynlik aan die Voortrekkers se verbondsteologie te danke dat hulle nogal reëlmatig as 'Outestamentiese gelowiges' aangedui word. As egter in ag geneem word dat á Brakel die genadeverbond, waarvan Jesus Christus die Middelaar is, beskryf as die verbond wat direk na die sondeval gesluit word (Gen 3: 15), en dat al die ander verbondsluitings slegs bevestiging van die genadeverbond is, is dit verstaanbaar dat die Ou Testament nie as die verbygegane beoordeel word nie, maar as prinsipieel één met die Nuwe Testament.

Daarby is dit duidelik dat vir die Voortrekkers die beskrywing van die volkslewe in die Ou Testament, nie ' $n$ saak was wat nét Israel gegeld het nie. Uit á Brakel en ook die ander oude schrijvers blyk dit dat die volkslewe van Israel paradigmatiese betekenis het, want daar word die grondlyne getrek van die gestalte wat die Christelike gemenebes moet dra. Daarom is dit miskien ook nie so vreemd dat die Voortrekkers soms na hulle leiers as rigters/regters (Preller 1920/I: 297) verwys nie. Die Voortrekkers het, op die patroon van die Calvinistiese teokrasie, die kerk in die wêreld gestruktureer en rondom die kerk, die samelewingspatroon vanuit die kerk vorm gegee, sodat die hele volkslewe in diens van God en tot eer van God sou bestaan. Uit die Ou Testament word dit duidelik dat God self eis dat die hele volkslewe, onder kerklike en burgerlike owerheid, daar is om Hom te dien, te prys en te eer. Die koninkryk van God is nié 'n saak wat eers in die Nuwe Testament na vore kom nie, maar dit is die roeping en doel van die 
Godsvolk, die verbondsvolk wat as heilige volk in die wêreld moet staan (á Brakel 1736/II: Hoofstukke 1 en 2). Daarom is dit vanselfsprekend dat die Voortrekkers ook en juis die Ou Testament so sorgvuldig gelees en probeer naleef het en parallelle gevind het tussen die geskiedenis van die ou volk en hulle eie bestaan. Dit het nie van hulle 'Outestamentiese gelowiges' gemaak nie asof dit sou beteken dat hulle Jesus Christus as Middelaar en Borg nie geken het nie. Op die voetspoor van á Brakel het hulle die Ou Testament gelees as 'n onafskeidbare deel van die Heilige Skrif waarvan Jesus Christus ook die sentrum was. Miskien bly die opmerking van Van Ruler (1945: 281) tog waar dat elke teokrasie nie anders kan as om Ou-Testamentiese karakter te vertoon nie. Dat die Voortrekkers se beklemtoning van die volk, as 'n organiese grootheid wat die basis van die gemenebes vorm, soms verkeerd verstaan is, en dat geoordeel is dat hulle die opvatting van die sekulêre volksoewereiniteit aangehang het, is miskien verstaanbaar, maar nie verskoonbaar nie. Hier lê waarskynlik ook 'n oorsaak van die opmerking in die Herderlijke Brief van die Sinode van die Kaapse kerk in Oktober 1837. Daar word gestel, nadat die Trek afgewys is (Dreyer 1929: 4):

'Voorts, Broeders en Zusters! betoont $u$ in den burgerstaat als eerlyke, arbeidzame en nuttige leder, der maatschappy, als getrouwe en gehoorzame onderdanen. Zoo zult gy gewis de bescherming en toegenegenheid wegdragen van hen die $u$ regeren. Zulks zal onder anderen eeue gunstige aanbeveling voor u zyn by Hare Majesteit onze Geliefde Koningin, wiens troonbeklimming gy moocht toejuichen, ....'

Dit is 'n tipiese voorbeeld van die staatkundige denke waar die majestas in die erfopvolgende vors geleë is. Veral in die Engelse dinkwêreld is die monargie gesien as die natuurlike borswering teen die opvattings van die volksoewereiniteit wat in Europa nie net die Franse Revolusie nie, maar ook Napoleon na vore gebring het. Skaars twaalf jaar na die Slag van Waterloo was in die Engelse wêreld die hele gedagte van volksoewereiniteit volkome onaanvaarbaar. Waarskynlik op die klank af en sonder om werklik te let op die inhoud van die Voortrekkergrondwette is die Groot Trek afgewys as ' $n$ versetdaad teenstrydig met die monargale staatsopvatting en die teologie wat dit moes ondersteun. Hier maak die Kaapse kerk 'n ongelooflike dom verklaring omdat die Skotte nie meer die geskrifte van John Knox geken het nie en Hollander- en Hollands-Afrikaanse predikante nie 
meer die geskiedenis van die gang van die Kerkhervorming begryp het nie. Waarskynlik mislei deur die opvattings van Wesley en die metodistiese lyn in die Nadere Reformasie, wat al die aandag gevestig het op die bekeerde gelowige en sy subjektiewe ervarings en strewe na heiligheid, is die forse Calvinistiese teokratiese denke op die agtergrond gestoot. ' $n$ Eksklusiewe kerkbegrip en 'n oormatige beklemtoning van die afstand tussen kerk en wêreld en 'n gebrek aan ' $n$ apostelêre visie het meegebring dat die Kaapse kerk die Voortrekkers teologies nie kon verstaan nie. Daarom is die Groot Trek veroordeel op 'n baie oppervlakkige politieke en teologiese basis en is ' $n$ saad gesaai wat nog wrange vrugte sou dra.

Samevattend ten opsigte van die Voortrekkers se vormgewing van hulle gemenebes of maatskappy, kan gestel word dat die visie van die Calvinistiese teokrasie waar die Ou Testament paradigmaties gelees en verstaan is, grotendeels hulle denke beheers het. Dit het meegebring dat die struktuur van die genadeverbond en wat daarmee saamgehang het, ' $n$ sentrale plek in hulle denke ingeneem het. Die genadeverbond wat die basis van hulle kerkbegrip was, het meegebring dat hulle die samehang van kerk-volk-owerheid in die sin van Artikel 36 NGB gesien het. Juis omdat kerk en volk by die Voortrekkers dieselfde was, was die organiese eenheid van kerk-volk-owerheid, soos dit gevind word in die Gereformeerde kerkstaat wat in 1651 in Nederland gevestig is, byna vanselfsprekend. Daarom kan gesê word dat met die saamval van kerk en volk in die Voortrekkerrepubliek dit vir die Voortrekkers grotendeels vanselfsprekend was dat die owerheid van die gedoopte volk, 'n Christelike owerheid sou wees wat as rigsnoer vir sy handelinge Skrif èn belydenis sou hê.

In hierdie basiese teokratiese denkpatroon het die opvattings van die Nederlandse Patriotte ogk deurgewerk en is sommige van dié opvattings oorgeneem. Dit is egter opvallend dat die Voortrekkers self nooit werklik 'n grondwet in die werklike sin van die woord optrek nie. Nieuwoudt (1979: 23) praat in hierdie verband van staatsreëlings en dit is waarskynlik die beste tipering van die drietal bespreekte dokumente. Die vroegste wat dit gebeur, is met die totstandkoming van die grondwette van die ZAR. Die Voortrekkers het basiese bepalende reëls vir die volksleiers en die Raad van Representanten opgetrek, maar nooit by ' $n$ volledige grondwet uitgekom nie omdat so iets nie in die teokratiese denkpatroon inpas nie. Tog is dit duidelik dat die Voortrekkers daardeur nie 'n ordelose gemeenskap was nie. Die teendeel is eerder waar en dit hang saam met die feit dat 'die Trekkers wou vashou 
aan wat deur die eeue heen as die insettinge van die volk van vader op seun, van generasie op generasie, oorgelewer is' (D Pont 1938: 87). Daarvoor was 'n geskrewe grondwet nie nodig nie en buitendien was die 'grondwet' van die teokrasie 'n Skriftuurlike gegewene waarmee almal vertroud was.

\section{ENKELE OPMERKINGS OOR DIE VORMGEWING VAN DIE VOORTREKKERSTAAT IN DIE OORVAALSE}

Die strewe van die Afrikaner na 'n eie tuiste en vaderland in die leë binneland van Suid-Afrika het saamgeval met die ontplooiing van die mag- en grondhonger Britse empire wat in Suid-Afrika beswaarlik aan die Afrikaner 'n staanplek gegun het. Daarom het die Voortrekkerrepubliek soos dit in 1840 bestaan het, ook maar 'n kort lewensduur gehad. In 1842 is Natal geannekseer en in 1848 is die Trans-Oranjegebied, wes van die Drakensberge, ook deur Engeland geannekseer. Dit het beteken dat die Oorvaalse gebied, wat deur Potgieter en Uys vir die Voortrekkers bewoonbaar gemaak is, oorgebly het.

In die Oorvaalse gebied, wat 'n toevlugsoord was vir die Voortrekkers wat nie onder die Britse vlag wou leef nie, het die onderlinge partyskappe en verdeeldhede, die ontwikkeling van die land ernstig benadeel (Pelzer 1950: $49 \mathrm{vv}$ ). Sonder om daarop in te gaan, kan gestel word dat in 1852 met die ondertekening van die Sandrivier-konvensie, genl AWJ Pretorius die onafhanklikheid van die Oorvaalse Voortrekkergebied erken gekry het deur Engeland. Daarna sou dit nog tot $1857 / 8$ duur voordat ' $n$ algemeen aanvaarde grondwet vir die ZuidAfrikaansche Republiek geskryf is (Nieuwoudt 1979: 30-31, 40). Die grondwet van 1857/1858 wat die grondreëls van die struktuur van die gemenebes neerlê, kan seker die merkwaardigste grondwet van die 19 de eeu genoem word. In 'n eeu waar die liberalistiese individualisme hoogty gevier het, waar uit pure sekulêre liberalisme die band tussen kerk en owerheid en kerk en volk losgemaak is, het grondwette ontstaan met ' $n$ minimum aan godsdienstige en kerklike inhoude. In daardie grondwette waar die regte van die enkeling-mens die voorrang gekry het en sy vryhede in die gemeenskap gewaarborg moes word, is die kerk gereduseer tot 'n genootskap of 'n vereniging waarby die landsburgers, as hulle wou, kon aansluit. Dan word die kerk nie meer werklik erken vir wat dit is nie, naamlik die godsdienstige keersy van die volk wat' $n$ land bewoon nie.

In die grondwette van die ZAR word, vir 'n groot deel, die denke van 
die Voortrekkers oor kerk-volk-owerheid as 'n organiese geheel, voortgesit. Die teokratiese denke, wat in Artikel 36 van die NGB verwoord is, is in hoë mate bepalend vir die grondliggende beginsels.

Die opvallendste kenmerk van die grondwette is die feit dat die volk hier aan die woord is. Verskillende bepalings begin met woorde soos: het volk eischt; het volk wil; het volk verkiest; het volk erkent; het volk verlangt. As op die grondwet van 1857/58 as 'n geheel gelet word, is dit duidelik dat hier sprake is van die volk as 'n organiese geheel, gevorm deur families met dieselfde taal, kultuur en godsdiens. Die belangrike is die versweë stelling dat dit ' $n$ Christelike volk is, deur die doop saamgesnoer in die genadeverbond en so in die kerk. Dat dít nie maar net 'n sydelingse saak is nie, blyk daaruit dat die volk, in die grondwet, hom ook duidelik uitspreek oor sy godsdiens èn sy kerk. Daarom bepaal die grondwet van 1858, wat inhoudelik nie baie verskil van dié van 1857 nie ( $\mathrm{J} \mathrm{H}$ Breytenbach s a: $496 \mathrm{vv}$ ):

'Art 8. Het volk laat de uitbreiding van het Evangelium toe onder de heidenen onder bepaalde voorzorgen tegen bedrog en misleiding.

Art 9. Het volk wil geen gelijkstelling van gekleurden met blanke ingezetenen noch in kerk noch in staat.

Art 20. Het volk wil zijne Nederduitsch-Hervormde Godsdienstleer, zooals deze in de jaren 1618 en 1619 door de Synode van Dordrecht is vastgesteld, in hare grondbeginselen blijven behouden, en de Nederduitsch-Hervormde Kerk zal de Kerk van den staat zijn.

Art 20. Het (volk) verkiest in zijn midden geen Roomsche kerken toe te laten, en ook geen andere Protestantshce, dan de zoodanige, waarin dezelfde hoofdzom van christelijk geloof geleerd wordt, als is opgegeven in den Heidelbergschen Catechismus.

Art 22. Het (volk) zal geen andere vertegenwoordigers in den Volksraad aanstellen, dan degenen, die lidmaten der Nederduitsch Hervormde Gemeenten zijn.

Art 23. Het volk erkent geen ander kerkelijk gezag, dan dat, wat door de Kerkeraden zijner Nederduitsch Hervormde gemeenten is of wordt goedgekeurd, aangenomen en vastgesteld volgens art 20.

Art 24. Het volk verlangt den opbouw, bloei en welvaart van Kerk en Staat en uit dien hoofde voorziening in de behoefte 
aan Nederduitsch-Hervormde Predikanten en school onderwijzers.'

Dit is allereers belangrik om daarop te let dat die volk die soewereiniteit dra en dat die volk die hoogste gesag gevoer het, ook oor die Volksraad. Daarom het die Volksraad ook deurgaans alle belangrike kwessies na volksvergaderings verwys (Nieuwoudt 1979: 31). Geleidelik het hierin wel wysigings gekom sodat later die Volksraad die hoogste gesag in die land gehad het (Nieuwoudt 1979: 43). Opmerklik bly dit egter dat die lede van die Volksraad altyd beskou is as verteenwoordigers van die volk, want die ou republiek het nie so iets soos georganiseerde politieke partye geken nie (Kleynhans 1966: $117 \mathrm{vv}$ ).

Dit is interessant om vervolgens 'n oomblik op Wypkema (1939: 334) se argument te let:

'De volkssoevereiniteit spreekt duidelik uit de Bataafse grondwet van 1798 . Het hoogste gezag van de staat beruste bij het volk. Dit beginsel blijkt uit verschillende bepalingen, waarbij de gehele regering en de rechten in de handen van het Bataafse Volk berusten. Verschillende artikelen beginnen met de woorden: Het Bataafse volk 'verkiest', 'verklaart', 'is overtuigd' en dergelijk uitdrukkingen van de volkswil, Hetzelfde zien we in de Transvaalse grondwet....

De volkswil, zoals uitgedrukt door de Transvaalse grondwet, berust op een veel hechter basis dan de volkswil, zoals vastgesteld door de Bataafse konstitusie. In Transvaal werd de volkswil feitelik in de grondwet gebracht door het volk zelf, terwijl in de Bataafse Republiek, niet door het volk, maar door een groep politici in de konstitutie de macht aan het volk werd gegeven.'

Dit mag so wees dat hierdie formulering van die volkswil tipies Frans en Bataafs is. Maar dan wil dit tóg voorkom asof die versweë omskrywing van die volk verskil. In die Frans-Bataafse denke is dit die demos, wat gevorm word deur die enkeling met sy regte en vryhede.

In Transvaal word die volk organies gevorm deur families, deur mense wat almal gedoop is en as sodanig die verbondsvolk vorm. Daarom word kerk en staat nié geskei nie, word slegs 'n bepaalde soort kerk in die ZAR toegelaat en word die onderwys óók kerklik bepaal. Dit is juis hierdie soort artikels wat daarop dui dat die volk waarvan die ZAR-grondwet praat, nie dieselfde is as die volk van die Bataafse Republiek se grondwet nie. Daarom lyk dit ook problematies om die 
Frans-Bataafse begrip volksoewereiniteit oor te dra op die Voortrekkers èn die Transvalers se beklemtoning van die volk as die draer van die soewereiniteit van die ZAR.

Wat hier van belang is, is dat die volk in die grondwet van 1858 die organiese eenheid van volk, kerk èn owerheid handhaaf en daarom ook die aard en die inhoud van sy geloof omskrywe en daarmee terselfdertyd, by implikasie bepaal, dat die owerheid daaraan gebind is. Daarom is Artikel 20 nie net van vormgewende belang vir de kerk van den staat nie, maar óók vir die owerheid. Hier word nie net inhoud gegee aan die kerk van die gedoopte verbondsvolk nie, maar ook aan die karakter van volk èn owerheid. Dit is duidelik dat hier op die voetspoor van Artikel 36 NGB gedink en geformuleer word. Daarom bepaal Artikel 21 dat die volk niě ' $n$ Roomse Kerk in sy midde wil hê nie omdat die Roomse Kerk in sy leer en belydenis die waarheid van die 'Nederduitsch-Hervormde Godsdientsleer zoo als deze in de jaren 1618 en 1619 door de Synode te Dordrecht is vastgesteld' weerspreek. Omdat die volk ' $n$ organiese eenheid is, daarom kan slegs ander Protestantse kerke verdra word wat dieselfde leer as die Heidelbergse Kategismus, handhaaf. Daarmee is die vadere nog steeds op die suiwer Calvinistiese lyn, aangesien in Genève 'n Engelse gemeente en in Nederland Franssprekende gemeentes bestaan het wat organisatories selfstandig was (vgl Nijenhuis 1959: 301-305).

Dat die owerheid, in die lig van Artikel 36 NGB, ook 'n taak het om die lewe rondom die kerk te kersten blyk uit Artikel 8 èn 24. Veral die noodsaaklikheid van Christelike onderwys vir die gedoopte kinders van die volk, is vanselfsprekend. Interessant is dat die ontwerp-kerkwet van 1857 in Artikel 35 kortweg bepaal: 'Het onderwys der jeugd staat onder het toezigt der kerk.' Hoewel die regering die onderwysers aangestel het, moes din 'in overeenstemming met den Kerkeraad' (Wypkema 1939: 477) plaasvind. Hierdie reëling het nie lank van krag gebly nie, want dan word die beginsel ingevoer dat die onderwys 'n taak en opdrag van die regering en niě van die kerk is nie. Daarom kom in die Kerkwet van 1862 nie 'n Artikel 35/1857 voor nie. Dit toon egter duidelik dat die ideaal was dat die gedoopte kinders van die volk nie 'n onderwys sou ontvang wat in stryd was met die leer van die kerk nie (Wypkema 1939: 477).

Ten opsigte van die sending blyk dit duidelik dat dit noodsaaklik geag word, maar die gekerstende Nie-Blanke word nie deel van die volk nie omdat hy nie as 'n landsburger kwalifiseer nie (vgl Engelbrecht 1953: 134-136). Hieroor kan daar lank uitgebrei word. Dit is 
egter duidelik dat volgens die kerkopvatting van die grondlêers van die ZAR die fisiese grense van die volkskerk saamval met die fisiese grense van die volk wat gevorm word deur die eenheid van families met dieselfde taal, kultuur en lewenstyl. Juis die bepaling van Artikel 8 en 9 van die 1858-grondwet, dui daarop dat owerheid èn kerk eenstemmig is dat die grens van volk en kerk skerp en duidelik moet bly.

Die trek van hierdie grens (Art 9) beteken nié dat die Nie-Blanke nie die evangelie mág hoor nie, maar dat hy die evangelie in die organiese verbande van sy bestaan en in sy eie leefwêreld, wat ánders is as dié van die Blanke, moet hoor en gehoorsaam. Deur á Brakel geleer, het die vadere geweet dat die deel-wees van 'n bepaalde kerklike struktuur nie die geloof bepaal nie en dat die eenheid van alle gelowiges nie in ' $n$ bepaalde struktuur verwerklik word nie. In die handhawing van hierdie suiwer Calvinistiese verstaan van die kerk het sowel die Voortrekkers as die grondlêers van die ZAR in beginsel gebots met die kerkbegrip en sendingmetodiek van die semi-pelagiaanse Metodisme wat in ons land al soveel onheil veroorsaak het.

So gesien was die Nederduitsch Hervormde Kerk in die ou Republiek vanselfsprekend volkskerk, soos dit was onder die Voortrekkers en soos in die situasie in die Kompanjiestyd. De Mist se skeiding van kerk en owerheid, kerk en volk, as sou die kerk as 'n soort bevooroordeelde gemeenskap nie geregtig wees om die godsdienstige keersy van die volk te wees nie, het niě die Voortrekkerdenke bepaal nie. Vir hulle was ' $n$ 'neutrale' owerheid onaanvaarbaar omdat hulle ten opsigte van die waarheidsvraag hulle waarskynlik ook deur á Brakel laat lei het (vgl á Brakel 1736/I: Hoofstukke 1 en 12). Opvallend is dat by die ontwerpkerkwet van 1857 ' $n$ besluit van die Algemene Kerkvergadering van 1857 toegevoeg is, waar gestel word (Breytenbach s a: 575 ):

'Art 1. Geen Gouvernement of wereldlyk bestuur heeft eenige magt in de kerk; dat is, het gouvernement beschermt de Kerk en bezoldigt hare leeraren, wordende het geheel en al aan de opzieners der Kerk overgelaten de inwendige zaken der Kerk te besturen en al dat gene te doen, wat duidelyk vervat is in de formulieren onzer Kerk over de bevestiging van ouderlingen, diakenen en Predikanten.

Geen Gouvernement of gouvernements-ambtenaar heeft als zoodanig regt, inzage te vorderen of te eischen van de inwendige Kerkelyke zaken, alleenlyk als ledematen der kerk kunnen zy op den daartoe vastgestelde tyd en plaats daarvan inzage nemen.' 
Met hierdie besluit loop die Algemene Kerkvergadering op die spoor van á Brakel wat met klem stel dat die owerheid alleen 'n gesag rondom die kerk het, maar geen mag in die kerk nie (Gerdener 1930: 222). Anders as in die Kaapse kerk waar die kommissaris-politiek baie lank sittingsreg op die kerklike vergaderings gehad het, word dit hier summier afgewys. Terselfdertyd word die jus patronatus van die owerheid wat in Natal nog deur die Voortrekker-Volksraad ten opsigte van die predikante uitgeoefen is, hier ook afgewys. Die enigste punt waarin á Brakel nié gevolg word nie, is sy stelling (á Brakel 1736/I: 693):

'De Overheden hebben een bedwingende macht omtrent de kerkelyke saken. Namentlyk om de kerkelyke persoonen, predikanten, ouderlingen en diakenen, haer plicht te doen waernemen datse die niet versuymen, dat sy blyven by de na Godts Woordt vastgestelde Kerken-ordere. Dat se die welke de kerke door valsche leeringen ende quade zeden, ende de Politie door quade maximen ende menigingen in Polityke saken beroeren, politykelyk weeren ende hinderen voort te varen. Datse de valsche Godtsdiensten vytroeyen; datse de kerke, alsse nu geheel bedorven is in leere ende in zeden, helpen reformeeren ende vyt die quade gestalte helpen door alle polityke middelen die te bedenken zyn, de tegenstanders bedwingen, de verlaters van de Godtsdienst tot haer pligt te brengen, etc.'

Hierdie taak, meen á Brakel, kom die owerheid toe omdat die owerheid die uitvoerder moet wees van al twee tafels van die Tien Gebooie. Dit wil egter voorkom asof á Brakel die optrede van die owerhede om die Remonstrantse twiste tot 'n einde te bring, hier tot beginsel verhef. Daarom het die Kerk á Brakel op hierdie punt nié gevolg nie, maar slegs die ander sake wat á Brakel noem, sorguuldig opgeteken. Dit is belangrik om daarop te let dat die feit dat die nasionale volkskerk ook staatskerk is, in die Transvaalse situasie nooit méér beteken het as dat die Volksraad die Kerkwet moes goedkeur èn dat die owerheid die voorreg gehad het om die traktemente van die predikante te betaal en die kerk te beskerm nie. Daarmee word ook die organiese eenheid van kerk en volk gestel.

Dit is nie vreemd dat die kerk in Transvaal as 'n volkskerk gesien èn waardeer is nie. Die maatskappy of gemenebes soos dit in die Oorvaalse gevestig is, was ondanks groepsverdelings en onderlinge geskille, 'n organiese eenheid of minstens op pad na so 'n organiese eenheidsbesef. In daardie, grotendeels eenvoudige situasie, was volk, 
kerk en owerheid byna vanselfsprekend in 'n eenheid saamgevoeg en was die kerk die godsdienstige keersy van die burgerlike samelewing. Dit is belangrik om dit te beklemtoon, want daaruit word dit duidelik dat die Frans-Bataafse opvatting van 'n skeiding tussen kerk en burgerlike gemeenskap of selfs die antitese tussen kerk en wêreld, nog nie dáár' $n$ rol van belang gespeel het nie.

Dit blyk, onder andere, dááruit dat dit die 'gezamentlijke Krijgsraad met de twee leden van de Volksraad' van Rustenburg was, wat die eerste Algemene Kerkvergadering in Augustus 1853 belê het. Hoe sterk dié organiese eenheid beleef is, blyk uit die 'politieke testament' van genl AWJ Pretorius wat hy op sy sterfbed gemaak het.

Om die organiese, byna vanselfsprekende eenheid of samehang van kerk en owerheid te bewys, is nie werklik moeilik nie omdat talle verskillende voorbeelde daarvan aangehaal kan word. Hoewel dit nêrens in soveel woorde skriftelik vasgelê word dat die kerk algemeen aanvaar word as die godsdienstige keersy van die burgerlike maatskappy en dat die owerhede en gesagsdraers 'n opdrag het om die kerk te beskerm nie, kan miskien op die volgende paar voorbeelde gelet word waaruit blyk dat die godsdienstige en kerklike opvattings vir 'n baie groot deel die denke van die grondlêers van die ZAR bepaal het.

Uit die periode voor die totstandkoming van die Grondwet 1857/58 kan gelet word op genl AWJ Pretorius se 'politieke testament', wat hy aan die Krygsraad gerig het en waarin hy stel (Engelbrecht 1953: 90):

'Nu in mijn zwakheid moet ik ulieden ook nog vermanen, protecteer uwe kerk. Zoo de kerk onder u vervalt, dan vervalt uwe staat, dan vervalt de zegen van land en volk, zoodat gijlieden in geene zaken zult bevorderlijk zijn.'

Dit is in daardie situasie waar daar nog nie 'n afstand tussen kerk en owerheid en kerk en volk bestaan nie, 'n volkome vanselfsprekende opdrag aan die Krygsraad.

'n Tweede voorbeeld is die gebeure waar die Volksraad en die Algemene Kerkvergadering in November 1853 in Potchefstroom in 'n samesitting oor die verwerping van die inlywing by die Kaapse Kerk, vergader en saam praat en saam besluit. Soos reeds by die Rustenburgse Algemene Kerkvergadering besluit is, word ook hier wéér aanvaar: 'burgerlijk vrij en onafhankelijk, wenschen wij dit ook in het kerkelijke'. Dié besluite lê volkome in lyn met die besluite wat die Voortrekkers aan die Vetrivier in 1837 geneem het.

As derde voorbeeld, uit die periode ná die aanvaarding van die 
grontwet van die ZAR, kan gewys word op die pogings wat die Uitvoerende Raad van die $Z A R$ in 1860 onderneem het om die afskeiding van ds $D$ Postma en die synes ongedaan te maak. Net so interessant is die feit dat dit die Uitvoerende Raad is wat in daardie selfde jaar ' $n$ poging van die Algemene Kerkvergadering om 'kerkelijk vereenigd te worden met de Kaapsche Synode' verongeluk deur Artikel 11 van die grondwet van die ZAR te handhaaf (Engelbrecht 1953: 168-169) waar gestel word (Breytenbach s a: 497).

'Het volk behoudt uitsluitend aan zich de bescherming en verdediging van de onafhankelykheid en onschendbaarheid van kerk en staat, overeenkomstig de wetten.'

Hieruit blyk hoe nou die verbondenheid van kerk en volk, kerk en owerheid was. Hiermee word ook, as vanselfsprekend, die riglyne wat in Artikel 36 NGB neergelê is, gevolg.

Die voorbeelde sou, indien nodig, met verskillende ander uitgebrei kan word. Die feit bly staan dat die organiese eenheid van volk, kerk en owerheid vir die burgers van die ZAR nie net ' $n$ teorie nie, maar ' $n$ lewende werklikheid was. Hierdie basis dat die volk 'n gedoopte verbondsvolk en almal deel van dieselfde kerk was, het 'n eenheidsband daargestel wat nie sonder invloed was nie.

Dit is van belang om daarop te let dat daar feitlik nog géén omvattende navorsingsresultate gepubliseer is wat die denke en opvattings van die Voortrekkers en hulle nasate vanuit hulle kerklik-godsdienstige opvattings analiseer nie. Dit hang saam met die feit dat die inhoud van die geskrifte van die oude schrijvers wat deur die Voortrekkers en hulle onmiddellike nasate gelees is, grotendeels onbekend is en die invloed dáárvan dus nog nie werklik in diepte gepeil is nie. Uit hierdie terreinverkenning wil dit voorkom dat méér aandag aan hierdie faset gegee sal moet word om sodoende tot ' $n$ beter begrip te kom van die opvattings van die grondlêers wat die fondamente van die Afrikaner se onafhanklike republieke in die vorige eeu gebou het (vgl Malan 1981: 44-45). Die opsigtelike gebrek aan geskrewe bronnemateriaal vir so 'n studie is waarskynlik die primêre oorsaak dat hierdie faset van ons volks- en kerklike verlede nog so weinig aandag geniet het.

\section{ENKELE OPMERKINGS OOR DIE KERKLIKE STRUKTUUR}

Ter afsluiting is dit nodig om 'n oomblik aandag te gee aan die struktuur wat aan die kerk in die ZAR gegee is. Daarin moet miskien, in 
hoofsaak, aandag gegee word aan die vraag of die noue verbintenis tussen kerk en volk die kerkbegrip dalk skeefgetrek het. Dit is immers één van die primêre besware teen die volkskerk dat die nasionaalkulturele die inhoud en karakter van die kerk sal bepaal of skeeftrek. Wanneer oor die struktuur van die kerk in die ZAR gepraat word, is dit belangrik om daarop te let dat die basiese uitgangspunte oor en van die kerk in die grondwet, Artikel 20, vasgelê is. Dáár word die inhoud van die kerk aangedui as die 'Nederduitsch-Hervormde Godsdienstleer, zooals deze in die jaren 1618 en 1619 door de Synode van Dordrecht is vastgesteld'. Die Reformatoriese leer soos omskrywe in die drie Formuliere van Eenheid, dit wil sê: die Nederlandse Geloofsbelydenis, die Heidelbergse Kategismus en die Leerreëls van Dordrecht, was dus die formele omskrywing van die leer van die staatskerk (Gerdener 1930: 235).

Wat die vormgewing van die struktuur van die kerk betref, is daar twee kerkwette waarna gekyk kan word. Die een is die ontwerp-kerkwet van 1857. Reeds in 1856, as die organisatoriese verbondenheid met die Kaapse kerk afgewys word, is gestel (Wypkema 1939: 450):

'... dat alhier voor ons eigen kerkestaat een wet zal gevormeerd worden, overeenkomstig de leer des Nederduits gerevormeerde Bijbels.'

In 1857 is ' $n$ Kerkwet, wat deur ds Van der Hoff in navolging van die Kaapse kerkwette opgestel is, aan die Algemene Kerkvergadering vir goedkeuring voorgelê. Hoewel dié vergadering die wette goedgekeur het, is dit nooit deur die Volksraad goedgekeur nie en het dit waarskynlik nooit regsgeldigheid gehad nie (Gerdener 1930: 221-222). Die indruk is egter dat hierdie Kerkwet wel in die kerk self gebruik is, want by die bekendmaking van die Wet het ds Van der Hoff in die Staatskoerant, 28 Mei 1858 (Breytenbach s a: 557-558), gestel:

'Ofschoon deze Kerkewetten reeds van het begin dezes jaars zyn in werking getreden, zoo blyven zy echter nog een geheel vol jaar na deze bekendmaking ter beoordeling aan de gemeente overgelaten, en wordt mitsdien elk en een iegelyk die lidmaat der gemeente is, uitgenoodigd, zyne aanmerkingen, die hy op dezelve mogt willen maken, schriftelyk met onderteekening van zyn naam, by my in te zenden in den loop van dit jaar 1858 , zullende al zulke aanmerkingen, die op Gods Woord gegrond zyn, in dank ontvangen en by de eerstkomende Vereenigde Kerkeraadsvergadering overwogen en beoordeeld worden.' 
Met die opstel en uitgawe van hierdie Kerkwet is ook uitvoering gegee aan die besluit van die Algemene Kerkvergadering, Desember 1857, waar vasgestel is (Gerdener 1930: 221):

'Onze Nederduitsch Gereformeerde Kerk beschouwt zich onafhankelyk van alle andere kerken, wat hare kerkelijke, wetten, huishoudelijke bepalingen, regering en bestuur betreft, - doch door den geest der christelijke liefde volgens het $\mathrm{H}$ Evangelie verbonden met alle ander Gereformeerde kerken over de geheele wereld; zoo verbonden dat wij, wanneer het vereischt mogte worden, elkander mogen beroepen tot instandhouding onzer kerk volgens bevel van onzen Zaligmaker, den Heere Jezus Christus, het enige Hoofd der kerk.'

Dié 1857-ontwerp het op die Algemene Kerkvergaderings nie weer aan die orde gekom nie, hoofsaaklik vanweë die feit dat vanaf vroeg in 1859 al die aandag in beslag geneem is deur die kontrovers oor die sing van gesange in die godsdiensoefening en die afskeiding te Rustenburg. By die beoordeling van die ontwerp-Kerkwet van 1857 is die verwantskap met die Kaapse Kerkwette ooglopend, en dienooreenkomstig ook die invloed van die rasionalistiese vereniginsreg wat tot in so ' $n$ hoë mate die Nederlandse Algemene Reglement van 1816 en die daarby komende reglemente bepaal het. Daar is twee groot besware téén die soort kerkwette: 1) Die kerk word gereduseer tot 'n genootskap waarin die institutêre volkome oorheers en waarin vergeet word dat die kerk 'n geloofsgemeenskap is, tegelyk instituut en organisme - die lewende liggaam van Christus wat deur die verkondiging van die Woord in aansyn geroep, onderhou en uitgebrei word (Milner 1970: $179 \mathrm{vv}$ ). 2) Hierdie soort wette maak dit,vir die kerk as 'n geheel onmoontlik om as 'n belydende kerk in die wêreld te staan. Dit word veral onderstreep deur die feit dat die kerkraad èn die meerdere vergaderings as ' $t$ ware belet word om leer en belydenis te handhaaf deurdat dit nie meer werklik vergaderings is waar verteenwoordigers van die leer- en regeerampte byeenkom om ook dáárdie deel van hulle ampswerk te verrig nie (Rasker 1974: $162 \mathrm{vv}$ ).

Wat die genootskaplike karakter betref, is dit so dat dit nêrens gesê word dat die kerk 'n genootskap is nie. Met ander woorde, daar word 'n wig geslaan tussen kerk en volk as sou dit twee afsonderlike en vreemde groothelde wees. Hier is dit ook opvallend dat die kerk sélf nie 'n afstand probeer skep tussen kerk en volk nie. Dit blyk daaruit dat die kerk in beginsel as ' $n$ lewende liggaam (Art 27-32 NGB) gesien word 
met 'n organisatoriese vormgewing wat nie in die pad staan van die feit dat Jesus Christus as Hoof van die kerk erken en bely word nie. Dat die verkondiging in die sentrum van die kerk se werk staan, word baie duidelik uit Artikel 23b waar gestel word (Breytenbach s a: 563):

'Zy zyn gehouden (dit is die predikante - ADP) gezettelyk te prediken, inzonderheid ook over de Catechismus, en de lydensgeschiedenis van onzen Heer; van tyd-tot-tyd belydenisleer-redenen te houden, en de gewone voorbereidings en nabetrachtings-leerredenen, voor en na het Heilig Avondmaal.'

Volkome in lyn met die feit dat die genadeverbond die onderbou is van die kerk en sy orde, word die lidmaatskap van die kerk omskryf as diegene wat deur belydenis van geloof lidmate geword het, diegene wat in die kerk gedoop is, èn diegene wat met 'n bewys van lidmaatskap of doop, deel van die kerk geword het.

Wat die belydenis betref, is dit afgesien van Artikel 20 van die grondwet, duidelik dat dít steeds norm en inhoud van die prediking moet wees (Art 8) en dat dit ook die lewenswandel van almal in die kerk normeer. Belangrik is hier Artikel 9 wat stel (Breytenbach s a: 560):

'Beschuldigingen tegen de leer van een Predikant, zullen inhouden duidelyke bewyzen dat hy de leer, welke volgens Gods heilig Woord, vervat is in de aangenomen formulieren van eenigheid der Gereformeerde Kerk, heeft wedersproken of bestreden.'

Dat die handhawing van dié leer nie in die lug bly hang nie, blyk uit Artikel 10 en 11 en ook uit die Reglement op de uitoefening van Kerkelyk opzicht en tucht waar Artikel 2 stel (Breytenbach s a: 569):

'Behalve dat deze onderscheidene vergaderingen zich tot hoofddoel stellen de handhaving van de Godsdienst, byzonder der Gereformeerde leer, en de zuiverheid van zeden welke haar is aanbevolen, zoo nemen zy daarenboven kennis van daden en handelingen die stryden tegen de kerkelyke wetten en verordeningen.'

In hierdie Reglement is Artikel 7 interessant omdat daar 'n soort sondelys voorkom, soos die Convent van Wezel 1568 en ander vroeë kerklike uitsprake dit geformuleer het.

Slegs uit hierdie enkele voorbeelde is dit baie duidelik dat die feit dat die kerk volkskerk was, nie die kerklike karakter van die kerk 
bepaal het nie. Buitendien is dit so dat die feit dat die kerk voluit kerk was, en nie 'n genootskap nie, nie alléén deur die struktuur van die kerk bepaal word nie. Die omstandighede waarin die kerk leef èn werk, die kwaliteit en gerigtheid van die prediking en die wyse waarop die lidmate hulle geloof uitlewe, kortom die hele kerklike lewe sélf, bepaal of die kerk werklik liggaam van Christus, verbondsvolk van God is. Dit alles kan moeilik uit die struktuur alleen afgelees word.

Dit is egter problematies om dit alles ten opsigte van die kerk in die ZAR in daardie vroeë jare na te vors, omdat al die materiaal nie beskikbaar is nie. Daarom kan slegs uit die beskikbare dokumente afleidings gemaak word met inagneming van die betreklikheid daarvan.

Dieselfde geld van die Kerkwet van 1862/63. Dié Kerkwet is ook maar ' $n$ betreklike aanduiding van wát in die kerk geleef het. In sekere opsigte is die geskiedenis hier 'n beter bron om vas te stel hoe die kerkas-geheel geleef en gewerk het. Wanneer na die Kerkwet gekyk word wat in 1863 deur die Volksraad goedgekeur is, val dit op dat dit heelwat van die 1857-ontwerp verskil. Presies wát die rede was dat die 1862Kerkwet soveel van die 1857-ontwerp verskil, kan nie meer vasgestel word nie. Tog moet steeds onthou word dat die Kerkwet van 1862 funksioneer binne die basiese grondreëls wat vir die kerk in die grondwet van die ZAR neergelê is.

Op die Algemene Kerkvergadering van September 1861 is aan die predikante Van der Hoff, Begemann en Smits opdrag gegee om die kerklike wet te hersien (Gerdener 1930: 255). Dit word so gedoen en dit wil voorkom asof daar in die 1863-wet baie sterker staatgemaak is op en oorgeneem is uit die Nederlandse reglemente as in 1857 (Wypkema 1939: 455).

As hierdie Kerkwet beoordeel word (vgl Pont [1963]: $36 \mathrm{vv}$ ), dan val dit op dat die verhouding met die owerheid nou nie meer volgens die opvatting van á Brakel gereël word nie, maar dat Artikel 41 slegs stel dat die Algemene Kerkvergadering 'staat in onmiddelyk verband met den Volksraad'.

Wat die genootskaplike karakter betref, bly dit waar dat hoewel die Kerk homself nêrens as 'n genootskap aandui nie, die verenigingsreg baie sterker in die struktuur ingebou word. Dié verenigingsreg wat die kerk reduseer tot ' $n$ genootskap in die volk, het die ander nadeel dat dit die kerklike ampte verhinder om voluit die dienswerk te verrig soos dit byvoorbeeld in die Bevestigingsformuliere omskryf word. Daarvan gee die 1862-Kerkwet egter nie blyke nie. Selfs wat die vergadering van die ampte betref, bly dit breë verteenwoordigende vergaderings waar in- 
derdaad na Woord en belydenis geluister is. Tog het dit die nadeel dat die belydende karakter van die Kerk minder duidelik na vore kom. Artikel 12 verwys egter nog pertinent na die handhawing van die leer en in die Reglement voor Kerkelijk Opzicht en Tucht, Artikel 3, word ampsdraers en lidmate tugwaardig geag as hulle hulle sou skuldig maak aan 'openbare strijd met den geest en de beginselen van de belijdenis'. Deur die navolging van die Nederlandse kerkwetlike reëlings en ook die Kaapse Kerkwet van 1842, het die kerklike strukturering sterker as in 1857 in die vaarwaters van die verenigingsreg en sy opvattings beland. Die wysigings wat in 1869 aan hierdie Kerkwet aangebring is, het daaraan nie veel verander nie.

Dit is egter duidelik dat hierdie kerkordelike aksentsverskuiwing nie plaasgevind het vanweë die feit dat die Kerk volkskerk was nie, maar dat die Nederlandse voorbeeld te sterk nagevolg is. Daarby kan in ag geneem word dat die kerkordelike formulerings nie die belydende karakter van die kerk of sy wil om die leer suiwer te handhaaf, verminder het nie. Dit blyk duidelik uit die gebeure rondom ds A] Begemann in 1872 (Engelbrecht 1953: 261).

Die organiese verbondenheid volk-kerk-owerheid wat selfs in die beginjare van die ZAR vanselfsprekend was, is egter van owerheidskant geleidelik afgewater. Soos ander invloede, opvattings en denkrigtings ook in die ZAR posgevat het, is die teokratiese siening van kerkvolk-owerheid geleidelik laat vaar en is ander insigte as die Calvinistiese gevolg. Dit het meegebring dat hoewel die Kerkwet van 1869 nog deur die Volksraad goedgekeur is, die owerhede self die band losser wou maak. Onder president T F Burgers is ' $n$ pad ingeslaan wat daarop uitgeloop het dat die Volksraad in 1886 bepaal het dat daar nié meer 'n staatskerk sou wees nie (Wypkema 1939: 465). Soos die oorspronklike, byna homogene gemeenskap in die Oorvaalse, beinvloed is vanuit ander oorde het die oorspronklike organiese verbondenheid losser geword. Kerklike verdeeldhede wat onder andere saamgehang het met verskillende opvattings oor die kerk en hoe dit verstaan moet word, en verskille oor die verhouding tussen die kerk en die owerheid, asook die verhouding tussen kerk en volk, het meegebring dat die gedagte dat die kerk-van-die volk óók staatskerk moet wees, geleidelik losgelaat is. Die Hervormde Kerk wat egter die doopverbond, die genadeverbond, as die fondament van sy ekklesiologie bly sien het, het daarvoor gekies om volkskerk te wees, al was dit so dat die organiese band tussen volkkerk-owerheid al losser geword het. Daarom het die Hervormde Kerk 
nog altyd Artikel 36 NGB onverkort en onveranderd in sy belydenis gehandhaaf.

\section{SLOTOPMERKINGS}

Dit is uit die voorafgaande duidelik dat die Calvinistiese opvatting van die genadeverbond, soos dit veral deur middel van á Brakel bekendheid gekry het, ' $n$ belangrike invloed uitgeoefen het op die verstaan en gebruik van die begrippe volk, kerk en owerheid en die onderlinge samehang daarvan. Dit is verder duidelik dat hierdie navorsing ten opsigte van á Brakel se invloed, opgevolg sal kan word met 'n verdere studie van die bydraes wat die ander oude schrijvers gelewer het. Tot dusver is dié oude schrijvers slegs geraadpleeg om daarmee die godsdienstige wêreld van die Afrikaner van die vorige eeu te probeer peil (Malan 1981: 44-45), maar nie sy opvattings oor kerk-volk-owerheid nie.

'n Saak wat ook nog aandag kan kry, is die vraag in hoeverre die ou Hervormers wie se denke deur hulle volkskerk-opvattings bepaal was, nie juis vanweë daardie opvatting so naïef in die kerkvereniging ingeloop het nie. As dit 'n argument is dat die nasionaal-politieke eenheidsbesef, wat die Transvaalse volk èn die Afrikaner in Suidelike Afrika na die oorlog van $1880-1881$ so sterk beinvloed het, die stimulans vir die kerkvereniging was, dan moes dit beslis in die volkskerk deurgewerk het. Dit bly egter merkwaardig dat dié saak, naamlik die verband: doop-genadeverbond-kerk, nie in die diskussies vanaf 1882 na vore gekom het nie. Dit is juis die opvallende dat die diskussie oor die verskil in kerkbegrip en die verhouding tussen kerk en volk nooit plaasgevind het nie. Moontlikk vanweë die koddige aanval van ds HL Neethling op die Hervormde Kerk as sou die kerk nie 'wettig' bestaan nie en ook 'liberaal' sou wees (Engelbrecht 1953: 287), het die diskussies in 1882 ook nooit werklik enige teologiese diepgang vertoon nie.

Dit is in ieder geval duidelik dat as gelet word op die uitsprake van die leidinggewende figure van die Konsulentsgemeente, was daar wat kerk en volk betref, 'n byna onoorbrugbare kloof in opvatting tussen die Hervormde en die Ned Geref Kerk.

Die kerkvereniging en die mislukking daarvan, het nie beteken dat die Hervormde Kerk sy siening dat hy 'n volkskerk is, laat vaar het nie. Die laaste keer wat die Kerk voor die oorlog van 1899-1902 hom hieroor uitgespreek het, was met die reorganisasie van die Algemene Kerk- 
vergadering van 1888 . In 'n Broederlijk Schrijven wat deur die vergadering uitgereik is, is gestel (Pont [1969]: 214):

'Onze kerk, de Nederduitsch Hervormde, is de kerk onzer vaderen, de kerk van het volk, dat de Republiek heeft gesticht .... Evenals den Staat wenschten zij de kerk in te richten, overeenkomstig de heilige verordeningen Gods, maar tevens als waarborg van hare staatkundige onafhanklikheid ....

Onze vaderen wilde zichzelven zijn; geene kerkelijke invloed van onderdanen van Engelsche bestuur: de mannen die de Republiek in het staatkundige gesticht hadden, gevoelden zich ook in staat een eigen kerk op te richten: voor het volk, om het volk en door het volk!

Hier is daar tog al 'n sekere aksentverskuiwing te bemerk. Die opvattings van die Voortrekkers en die grondlêers van die ZAR oor die organiese eenheid van kerk-volk-owerheid na aanleiding van Artikel $36 \mathrm{NGB}$ was besig om te vervaag. Dit is ook so dat, na die Algemene Kerkvergadering van 1888, die Hervormde Kerk nie weer oor sy karakter as volkskerk gehandel het nie. Dit is ook so dat die Calvinistiese siening dat die genadeverbond die basis vir die kerkbegip is, soos á Brakel en die ander oude schrijvers al minder gelees is, geleidelik op die agtergrond geraak het. So het die teokratiese visie van kerk en volk en owerheid al minder bewustelik in die uitspraak van die Kerk na vore gekom.

Tog was die invloed van die Hervormde Kerk en sy lidmate op die maatskaplik-kulturele en selfs politieke vlak nog van groot gewig in die jare na die kerkvereniging en tot by die uitbreek van die oorlog van 1899-1902 (Van Niekerk 1985: 73). Dit het saamgehang met die feit dat die Hervormde Kerk en sy lidmate die voortsetting was van die Voortrekkerdenke èn dié van die grondlêers van die ZAR. Bykomende navorsing en studie sal egter nog onderneem moet word om die invloed van die Hervormde Kerk op die maatskaplik-kulturele en politieke vlak in die ZAR te presiseer. Die feit dat die Kerk in die periode na 1886 in 'n krisissituasie gedompel was wat eers min of meer in 1894 beëindig is, het waarskynlik daartoe bygedra dat die Kerk op teologiese vlak nie baie aktief was nie.

Binne enersyds die raamwerk van die grondwet van die ZAR, wat 'n duidelike Christelike owerheid daargestel het, en andersyds die uitspraak van die Algemene Kerkvergadering van 1888, het die Hervormde Kerk sy laaste jare in die ZAR beleef. Dit is duidelik dat die 
agtergronde van die volkskerk-opvatting wat in die Hervormde Kerklike kring hanteer word, hiermee nog nie volledig uitgewerk is nie. Dit is duidelik dat daar nog ruimte vir verdere navorsing is. Dit is ook duidelik dat die bydrae wat vanuit die godsdienstig-kerklike leefwêreld van die Voortrekkers en die grondlêers van die ZAR in die vormgewing van hulle maatskappy en kerk gekom het, groter is as wat op die oomblik in ons geskiedskrywing aangedui word.

\section{Literatuurverwysings}

á BRAKEL, W 1736. Redelyke Godtsdienst in welke de goddelike waerheden des genadenverbondts worden verklaarts, tegen party en beschermt en tot de praktyke aengedrongen. Rotterdam: Wed $\mathrm{H}$ van den Aak.

ARMSTRONG, BG 1969. Calvinism and the Amyrault heresy. Madison: University of Wisconsin Press.

BAKER, JW 1980. Heinrich Bullinger and the covenant. Athens: Ohio University Press.

BEYERS, C 1969. Die Kaapse Patriolte gedurende die laaste kwart van die agtiende eeu en die voortlewing van hulle denkbeelde. Pretoria: Van Schaik.

BOESEKEN, AJ 1944. Die Nederlandse Kommissarisse en die 18de-eeuse samelewing aan die Kaap, in Argiefjaarboek vir SA Geskiedenis, Deel 7. Kaapstad: Die Staatsdrukker.

BOETZELAER, CW Th Baron van, 1947. De Protestantsche kerk in Nederlandsch Indië. 'sGravenhage: Nijhoff.

BOTHA, SJ 1973. Die volkskerk. Pretoria: HAUM.

BREYTENBACH, JH s a. Notule van die Volksraad van die Suid-Afrikaanse Republiek, Deel III, in Suid-Afrikaanse Argiefstukke, Transvaal Nr 3. Kaapstad: Die Staatsdrukker.

CALVINUS, J 1559. Institutio christianae religionis.

COERTZE, LI 1938. Die Majestas in die Voortrekkerstaat en die Unie, in Bosman, ID (red), Voortrekker-Gedenkboek van die Universiteit van Pretoria. Pretoria: Publikasiekomitee UP.

DE BIE JP en LOOSJES, J s a. Biographisch woordenboek van Protestantschen godgeleerden in Nederland, Dl 1. 's-Gravenhage: Nijhoff.

DE VISSER, J Th 1926. Kerk en staat, DI 2. Leiden: AW Sijthoff's Uitgeversmaatschappij.

DU PLESSIS, AJ 1943. Die republiek Natalia, in Argiefjaarboek vir SA Geskiedenis, DI 5/1. Kaapstad: Die Staatsdrukker.

ENGELBRECHT, SP 1953. Geskiedenis van die Nederduitsch Heroormde Kerk van Afrika. Kaapstad: HAUM- JH de Bussy.

GEY VAN PITTIUS, EFW 1938. Die vryheidsideale van die Voortrekkers, in Bosman, ID (red), Voortrekker-Gedenkboek van die Universiteit van Pretoria. Pretoria: Publikasiekomitee UP.

GEY VAN PITTIUS, EFW 1941. Staatsopvattings van die Voortrekkers en die Boere. Pretoria: Van Schaik.

GERDENER, GBA 1930. Boustowwe vir die geskiedenis van die Nederduits-Gereformeerde Kerk in die Transgariep. Kaapstad: Nasionale Pers.

HANEKOM, TN 1959. Helperus Ritzema van Lier. Kaapstad: NG Kerk-Uitgewers.

HAITJEMA, Th L 1964. De nieuwere geschiedenis van Neerlands Kerk der Heroorming. 'sGravenhage: Boekencentrum NV.

HEPPE, H 1958. Die Dogmatiek der evangelisch-reformierte Kirche. Neu durchgesehen und herausgegeben von E Bizer. Neukirchen: Neukirchener Verlag.

JACOBS, M 1971. Die evangelische Staatslehre. Göttingen. Vandenhoeck \& Ruprecht. 
KLEYNHANS, WA 1966. Volksregering in die Zuid-Afrikaansche Republiek: Die rol van memories. Pretoria: Van Schaik.

LASKI, HJ 1972. A defence of liberty against tyrants: A translation of the Vindiciae contra Tyrannos by Junius Brutus. New York: Burt Franklin.

LEONARD LEEB, I 1973. The ideological origins of the Batavian revolution. The Hague: Nijhoff.

LOCHER, GW 1979. Die Zwinglische Reformation im Rahmen der europäischen Kirchengeschichte. Göttingen: Vandenhoeck \& Ruprecht.

MALAN, CJ 1981. Die Nadere Reformasie. Potchefstroom: PU vir CHO. (Instituut vir die bevordering van die Calvinisme.)

MILLER, P 1939. The New England mind: The seventeenth century. New York: MacMillan.

MILNER, BC 1970. Calvin's doctrine of the church. Leiden: SJ Brill.

MOLSBERGEN, EC GODEE 1912. De stichter van Hollands Zuid-Afrika: Jan van Riebeeck. Amsterdam: SL van Looy.

MURRAY, AH. The political philosophy of JA de Mist. Cape Town: HAUM.

MURRAY, AH 1966. The Vindiciae contra Tyrannos, in Acta Juridica. University of Cape TOWn.

NEUSER, WH 1967. Kirche und Staat in Reformzeit, in Aland K (Hrsg), Kirche und Staat. Berlin: De Gruyter.

NIEUWOUDT, CF 1979. Die staatsreëlings van die Voortrekkers en die Boere, in Nieuwoudt, CF (red), Die politieke stelsel van Suid-Afrika. Pretoria: Academica.

NIJENHUIS, W 1959. Calvinus Oecumenicus. 's-Gravenhage: Nijhoff.

PONT, AD [1963]. Oor die Kerkwet van 1862. HTS 19.

PONT, AD [1969]. Kerk en volk. HTS 25.

PONT, AD 1985. Thomas Erastus oor die struktuur van die gemeenskap. HTS 41, 428-440.

PONT, D 1938. Die Betekenis van die Groot Trek vir ons Gemenereg, in Bosman, ID (red), Voortrekker-Gedenkboek van die Universiteit van Pretoria. Pretoria: Publikasiekommissie UP.

PONT, JW 1910. Het ontstaan van de Luthersche gemeente in Kaapstad, in Nieuwe bijdragen tot kennis van de geschiedenis en het wezen van het Lutheranisme in de Nederlanden, Dl 3. Amsterdam: Ten Brink en De Vries.

PELZER, AN 1950. Wordingsjare. Kaapstad: AA Balkema.

PRELLER, GS 1920. Voortrekkermense, DI I en II. Kaapstad: Nasionale Pers.

PRELLER, GS 1924. Voortrekker-Wetgewing. Pretoria: Van Schaik.

RASKER, AJ 1974. De Nederlandse Hervormde Kerk vanaf 1975. Kampen: Kok.

SCHAFF, P 1919. The creeds of Christendom. New York. Harper and Brothers.

SCHILDER, K 1977. Het verbond in de gereformeerde symbolen. Kampen: Copieerinrichting van den Berg.

SCHOON, HF 1897. Uit het dagboek van Erasmus Smit. Kaapstad: Townshend, Taylor and Snashall Drukkers.

SPOELSTRA, C 1906. Bouwstoffen voor de Geschiedenis der Nederduitsch-Gereformeerde Kerk in Zuid-Afrika. Amsterdam: HAUM.

VAN EIKEMA HOMMES, HJ 1979. Major trends in the history of legal philosophy. Amsterdam: North Holland Publishing Co.

VAN NIEKERK, LE 1985. Kruger se regterhand. Pretoria: Van Schaik.

VAN RULER, AA 1945. Religie en politiek. Nijkerk: Callenbach.

VORSTER, JD 1956. Die kerkregtelike ontwikkeling van die Kaapse Kerk onder die Kompanjie 1652-1795. Potchefstroom: Pro Rege-pers.

WENDEL, F 1978. Calvin. The origins and development of his religious thought. Transl by $P$ Mairet. Glasgow: Collins and Sons.

WESEL-ROTH, R 1954. Thomas Erastus. Lahr/Baden: Verlag Moritz-Schavenburg.

WYPKEMA, A 1939. De invloed van Nederland op ontstaan en ontwikkeling van de ZA Republiek tot 1881. Pretoria: JH de Bussy. 